\title{
Short time scales of magma-mixing processes prior to the 2011 eruption of Shinmoedake volcano, Kirishima volcanic group, Japan
}

\author{
Akihiko Tomiya • Isoji Miyagi • Genji Saito • Nobuo Geshi
}

Received: 28 February 2013 / Accepted: 6 August 2013 /Published online: 6 September 2013

(C) The Author(s) 2013. This article is published with open access at Springerlink.com

\begin{abstract}
We estimated time scales of magma-mixing processes just prior to the 2011 sub-Plinian eruptions of Shinmoedake volcano to investigate the mechanisms of the triggering processes of these eruptions. The sequence of these eruptions serves as an ideal example to investigate eruption mechanisms because the available geophysical and petrological observations can be combined for interpretation of magmatic processes. The eruptive products were mainly phenocryst-rich ( $28 \mathrm{vol} \%$ ) andesitic pumice $\left(\mathrm{SiO}_{2} 57 \mathrm{wt} \%\right)$ with a small amount of more silicic pumice $\left(\mathrm{SiO}_{2} 62-63 \mathrm{wt} \%\right)$ and banded pumice. These pumices were formed by mixing of low-temperature mushy silicic magma (dacite) and high-temperature mafic magma (basalt or basaltic andesite). We calculated the time scales on the basis of zoning analysis of magnetite phenocrysts and diffusion calculations, and we compared the derived time scales with those of volcanic inflation/deflation observations. The magnetite data revealed that a significant mixing process (mixing I) occurred 0.4 to 3 days before the eruptions (preeruptive mixing) and likely triggered the eruptions. This mixing process was not accompanied by significant crustal deformation, indicating that the process was not accompanied by a significant change in volume of the magma chamber. We propose magmatic overturn or melt accumulation within the magma chamber as a possible process. A subordinate mixing process (mixing II) also occurred only several hours before the eruptions, likely during magma ascent (syn-eruptive mixing). However, we interpret mafic injection to have begun more than several tens of days prior to mixing I, likely occurring with the beginning of the inflation (December 2009). The injection did
\end{abstract}

Editorial responsibility: P. Wallace

A. Tomiya $(\bowtie) \cdot$ I. Miyagi $\cdot$ G. Saito $\cdot$ N. Geshi

Institute of Geology and Geoinformation,

National Institute of Advanced Industrial Science and Technology

(AIST), Tsukuba Central 7, 1-1-1 Higashi, Tsukuba,

Ibaraki 305-8567, Japan

e-mail: a.tomiya@aist.go.jp not instantaneously cause an eruption but could have resulted in stable stratified magma layers to form a hybrid andesitic magma (mobile layer). This hybrid andesite then formed the main eruptive component of the 2011 eruptions of Shinmoedake.

Keywords Diffusion $\cdot$ Magma chamber $\cdot$ Magma mixing · Magnetite $\cdot$ Sub-Plinian eruption $\cdot$ Time scale

\section{Introduction}

Petrologic studies have revealed that pumice eruptions are often preceded by a mixing of mafic magma into preexisting silicic magma. These events, including the 1991 eruption of Pinatubo (Pallister et al. 1992), the 1663 eruption of Usu volcano (Tomiya and Takahashi 1995), the 1953-1974 eruptions of Southwest Trident volcano (Coombs et al. 2000), the 1929 eruption of Hokkaido-Komagatake (Takeuchi and Nakamura 2001), the Holocene zoned eruption of Volcán San Pedro (Costa and Chakraborty 2004), and many others, suggest that magma mixing triggers eruption. Geodetic studies have also revealed that inflation often occurs prior to eruptions (e.g., Segall 2010), suggesting that the associated magma chambers were over-pressurized by magma injection from depth. However, the relationship between magma injection, magma mixing, and eruption triggering is unclear because injection does not necessarily cause instantaneous mixing if the injected magma is sufficiently denser than the pre-existing magma and has formed stable stratified layers. In such a case, the underlying mafic magma exerts only thermal effects for some time (e.g., Huppert and Sparks 1988; Jellinek and Kerr 1999; Burgisser and Bergantz 2011). Therefore, it is necessary to combine detailed geophysical and petrologic studies to examine and understand pre-eruptive processes.

The 2011 eruption of Shinmoedake volcano, Kirishima volcanic group, South Kyushu, Japan, is an ideal example for such studies because many geophysical, geological, and 
petrological observations have been conducted on the event (see next section). In this paper, we estimated the timescales of magma-mixing processes prior to the climactic sub-Plinian events on the basis of zoning analysis of magnetite phenocrysts, and we compared them with the time scales of volcanic inflation/deflation processes.

Zoning profiles of phenocrysts have been often analyzed to estimate time scales of various magmatic processes (e.g., Costa et al. 2008). Olivine is one of the most useful minerals for such studies (e.g., Gerlach and Grove 1982; Nakamura 1995; Martin et al. 2008) because it commonly occurs in mafic magma, and its rapid $\mathrm{Mg}-\mathrm{Fe}$ interdiffusion enables timescales to be estimated at less than 1 month. Recently, $\mathrm{Mg}$ in plagioclase has been used to provide time scales of days to years (e.g., Costa et al. 2003, 2008; Druitt et al. 2012; Ruprecht and Cooper 2012). Magnetite phenocrysts are particularly useful in silicic magma systems for detecting the processes within days to months before eruption (e.g., Nakamura 1996; Devine et al. 2003; Chertkoff and Gardner 2004; Tomiya and Takahashi 2005) because of their rapid diffusion (Van Orman and Crispin 2010) and common occurrence in various types of magma. Titanium diffusion profiles of magnetite have often been analyzed to discuss time scales from magma mixing to eruption. Nakamura (1996) analyzed magnetite in dacite from the 1990-1995 lava-dome eruption of Unzen volcano, Japan, and determined time scales of less than several weeks, regardless of the time from the beginning of the eruption. Devine et al. (2003) analyzed magnetite in andesite from the lava-dome eruption of Soufrière Hills volcano, Montserrat, ongoing since 1995, and also determined similar time scales. Both of the authors concluded that injection of high-temperature magma into low-temperature mushy magma occurred continually for years during the dome eruption. Tomiya and Takahashi (2005) analyzed magnetite from one Plinian (rhyolite) and three sub-Plinian (dacite) eruptions of Usu volcano, Japan, and determined time scales of less than several days to several tens of days. They proposed that these time scales corresponded to the time of magma ascent because of similarity to the durations of the precursory seismicity of the eruptions. These studies for Unzen, Montserrat, and Usu all indicated timescales of days to weeks for magma mixing to eruption in silicic magma systems.

In this study, we examined diffusion profiles of $\mathrm{Al}$ and $\mathrm{Mg}$ in magnetite in addition to those of $\mathrm{Ti}$. $\mathrm{Al}$ and $\mathrm{Mg}$ are minor elements in magnetite and are useful indicators of magmatic conditions because their sensitivity to such changes is higher than that of the major component ulvöspinel (Usp); thus, they are suitable for detecting magma mixing (Tomiya and Takahashi 2005). As a result, we successfully determined short time scales of approximately 1 day for magmamixing processes prior to the 2011 eruption of Shinmoedake volcano.

\section{Shinmoedake volcano and the 2011 eruption}

Shinmoedake volcano is one of the major cones of the Kirishima volcano group, south Kyushu, Japan (Fig. 1). This volcano consists of lava flows that formed at least $15 \mathrm{ka}$ and a pyroclastic cone that formed approximately $9 \mathrm{ka}$ (Imura and Kobayashi 1991). It has been active since its largest eruption during the Kyoho era in 1716-1717 with repeated sub-Plinian activity, producing $1.7 \times 10^{11} \mathrm{~kg}\left(6.8 \times 10^{7} \mathrm{~m}^{3}\right.$ dense rock equivalent (DRE)) of pumice falls and pyroclastic flows. Between 1717 and 2008, small phreatic eruptions occurred in 1822, 1959, and 1991. Recent activity began on August 22, 2008, with a minor phreatic eruption (Geshi et al. 2010). In 2010, seven minor phreatic eruptions were also observed from March through July.

The 2011 eruption consisted of numerous eruption events (e.g., JMA (Japan Meteorological Agency) and Yamasato (2011); Miyabuchi et al. 2013). The first was a phreatomagmatic eruption on January 19, after which continuous fumarolic activity was observed in the crater. On January 26, a minor ash discharge started at 07:31 JST (UTC $+9 \mathrm{~h})$. The climactic events began on January 26 at 14:49 JST with phreatomagmatic explosions and included three sub-Plinian eruptions (e.g., Furukawa et al. 2011; Kozono et al. 2013) on that day from 16:10 to 18:40 JST (event P1), and on January 27 from 02:00 to 05:00 JST (event P2), and from 16:20 to 18:00 JST (event P3). The total eruptive volume of the sub-Plinian eruptions was (1.2 to 1.6$) \times 10^{7} \mathrm{~m}^{3} \mathrm{DRE}$ (Kozono et al. 2013). Lava effusion followed the P3 explosion and nearly filled the summit crater by February 1, 2011, forming a lava lake approximately $600 \mathrm{~m}$ in diameter, $100 \mathrm{~m}$ in depth, and $1.9 \times$ $10^{7} \mathrm{~m}^{3}$ in volume (Shimono et al. 2011). After the lava effusion, approximately 20 Vulcanian explosions were observed through April 2011. The erupted volume of each explosion was less than $10^{6} \mathrm{~m}^{3}$ (Oikawa et al. 2011). Since May 2011, only minor ash discharges and no Vulcanian explosions have been observed. These eruptions were effectively monitored by various geophysical observations including seismic, geodetic, and remote sensing monitoring (e.g., JMA and Yamasato 2011; Kawamoto et al. 2011; Shimono et al. 2011; Shimbori and Fukui 2012; Ueda et al. 2013).

\section{Analytical methods}

Samples were collected near Takachiho-gawara (points NF6 and ONHF326) and at Miike Elementary School (point MES) approximately $3 \mathrm{~km}$ south-southeast and $7 \mathrm{~km}$ southeast from the vent, respectively (Fig. 1b). These points are located along the main distribution axis of the sub-Plinian deposits (Furukawa et al. 2011). In this study, we concentrated mainly on the largest event, P2. Samples from NF6 were collected on the afternoon of January 27, 2011, between events $\mathrm{P} 2$ and $\mathrm{P} 3$. 


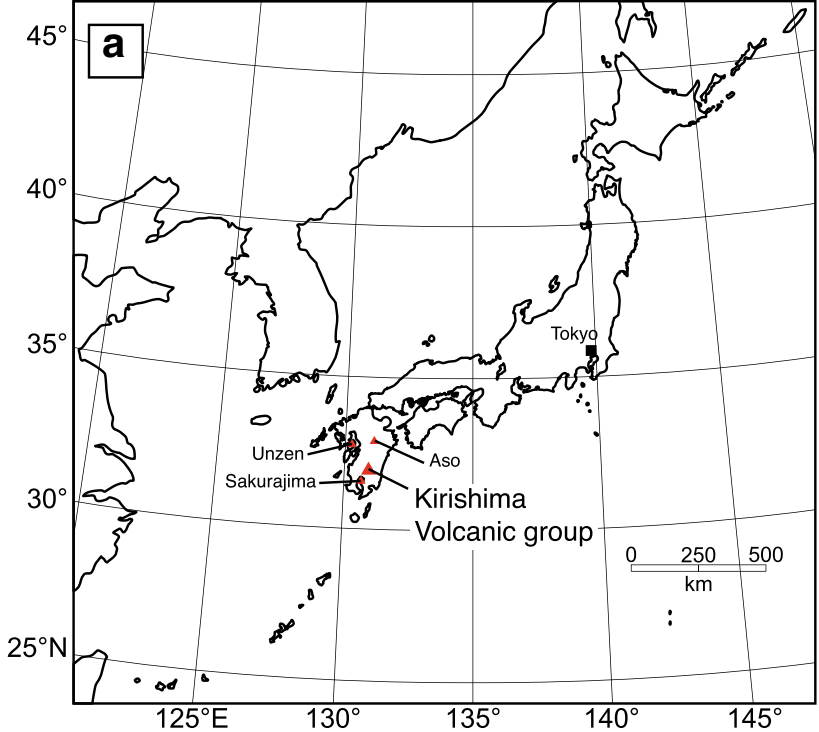

Fig. 1 a Index map of the Kirishima volcanic group. b A map of the Kirishima volcanic group. Among more than 20 eruption centers (red circles), Shinmoedake is located in the center of the volcanic group. Ohachi and Karakunidake are also active cones that have historical

Whole-rock compositions of the pumices were determined by X-ray fluorescence at the Geological Survey of Japan, National Institute of Advanced Industrial Science and Technology (AIST). The procedure was similar to that reported by Geshi (2008). Tephra grains were individually pulverized by using a tungsten carbide mill. Ten major elements were analyzed with a PANalytical Axios spectrometer. Glass beads were prepared by the fusion of $0.5 \mathrm{~g}$ of the sample and Li tetraborate at a ratio of 1:10. The external error and accuracy in the process were less than $2 \%$.

Chemical compositions of phenocrysts were analyzed with the JEOL JXA-8900R electron microprobe at the Geological Survey of Japan, AIST. Thin sections of pumices were polished and analyzed. The analytical conditions for quantitative analyses included a $15-\mathrm{kV}$ acceleration voltage and a $12-\mathrm{nA}$ probe current. Counting times for minor elements in magnetite including $\mathrm{Al}, \mathrm{Mg}$, and $\mathrm{Mn}$ were $60-90 \mathrm{~s}$, which is longer than the 20-s time for other elements ( $\mathrm{Si}, \mathrm{Ti}, \mathrm{Fe}, \mathrm{Ca}, \mathrm{Na}, \mathrm{K}$, and $\mathrm{P}$ ). The method reported by Stormer (1983) was used in the calculations of ferric/ferrous ratio and Usp component in magnetite.

Partitioning of minor elements in magnetite and melt has been discussed by many researchers (e.g., Sack 1982; Bacon and Hirschmann 1988; Lindsley 1991; La Tourrette et al. 1991; Toplis and Corgne 2002). Recently, Dare et al. (2012) compiled data on partition coefficients for major and trace elements between magnetite and melt, using the Geochemical Earth Reference Model database (http://earthref.org/GERM/). Partitioning of $\mathrm{Al}, \mathrm{Mg}$, and $\mathrm{Mn}$ between magnetite and melt strongly depends on the melt composition and the presence of co-existing silicate minerals because they are lithophile elements. It may also depend on mineral compositions,

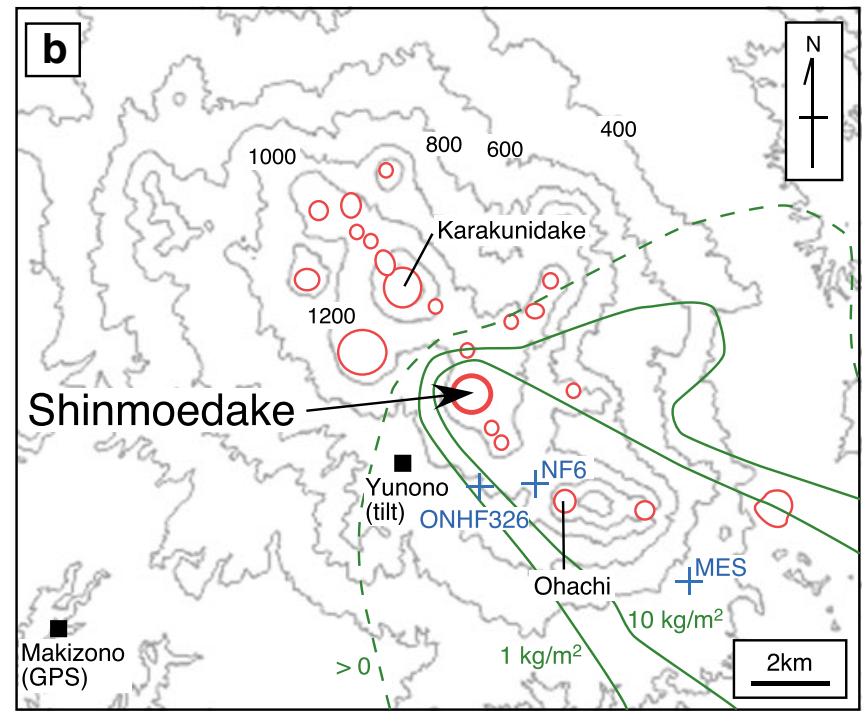

eruptions. Locations of sampling sites (ONHF326, NF6, and MES), Global Positioning System (GPS) station, and tiltmeter are shown. Isopleths for events $\mathrm{P} 1+\mathrm{P} 2$, indicated by green curved lines, are from Furukawa et al. (2011)

temperature, and oxygen fugacity; however, Toplis and Corgne (2002) reported that partitioning of divalent cations into magnetite is approximately independent of oxygen fugacity in spite of the fact that magnetite composition is a strong function of oxygen fugacity. For the magma compositions investigated here (calc-alkaline andesite), it is known that lithophile elements such as $\mathrm{Mg}(\mathrm{Mg} / \mathrm{Mn})$ and $\mathrm{Al}$ decrease in magnetite during fractionation of a silicate melt (e.g., Dare et al. 2012). Thus, we here refer to a zoning pattern that shows an increase in $\mathrm{Al}$ and $\mathrm{Mg}$ toward the rim as "reverse zoning."

\section{Results}

Compositions of bulk rocks, silicate minerals, and melt inclusions

The products of the sub-Plinian eruptions are composed mainly of phenocryst-rich ( $28 \mathrm{vol} \%$ on a vesicle-free basis) gray pumice of calc-alkaline andesite with a $\mathrm{SiO}_{2}$ content of $57 \mathrm{wt} \%$ (Figs. 2 and 3; Table 1). A small amount of andesitic-dacitic white pumice with an $\mathrm{SiO}_{2}$ content of $62-63 \mathrm{wt} \%$ and gray and white banded pumice (Fig. 2c) is also present. Chemical compositions of the gray pumices are similar to those of volcanic bombs and lapilli from Vulcanian eruptions during February 1 and 14 and gray pumice of the 1716-1717 eruption. Chemical compositions of the white pumices are similar to those of white pumice from the 1716-1717 eruption, that is, both eruptions show bimodal distribution in bulk rock compositions.

Phenocryst assemblage of the 2011 eruptive products includes plagioclase, clinopyroxene, orthopyroxene, olivine, magnetite, and ilmenite. This assemblage is common in gray, 
Fig. 2 Various types of pumice from the January 26-27, 2011, eruption. a White pumice; $\mathbf{b}$ gray pumice; $\mathbf{c}$ banded pumice with white streaks (arrow). Photos (a) and (b) were provided by Dr. T. Oikawa

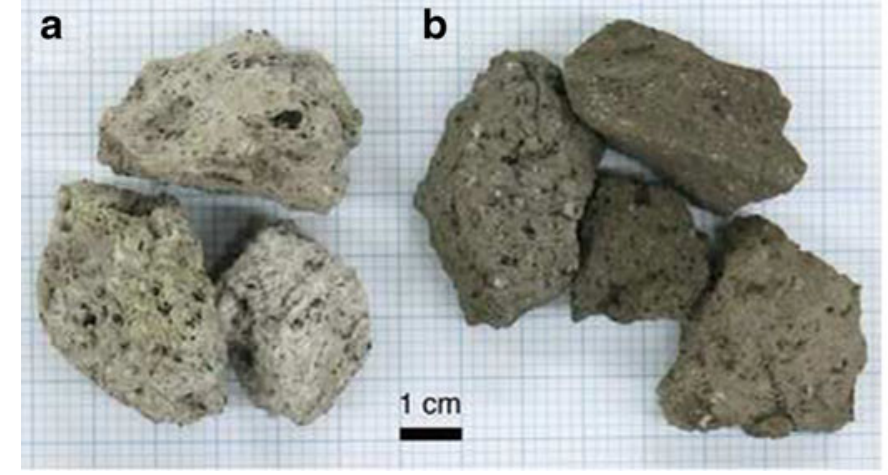

C

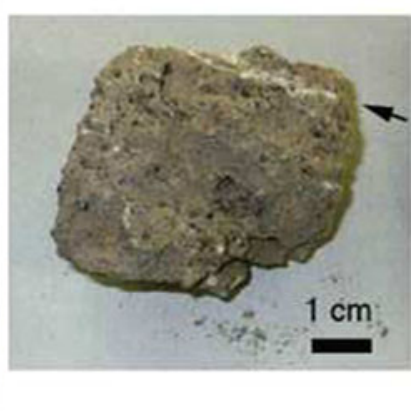

white, and banded pumices. Compositions of silicate minerals are shown in Figs. 4, 5, and 6 (after Saito et al. 2011). Recently, Suzuki et al. (2013) reported similar observations and obtained similar magma processes to those made in Saito et al. (2011) and this study, including mixing between silicic magma and mafic magma in short time scales. Plagioclase forms the dominant phenocrysts. Their zoning patterns are complex, showing oscillatory zoning, patchy zoning, and sieve texture. In addition, they exhibit variable compositions (An 51-92, where $\mathrm{An}=100 \times \mathrm{Ca} /(\mathrm{Ca}+\mathrm{Na})$ in moles; Fig. 4). Two peaks appear at approximately An 55 and An 90 in the core composition. The rim and groundmass compositions are generally An 70, which is between the two peaks. Clinopyroxene phenocrysts are relatively homogeneous in composition $\left(\mathrm{Mg}^{*} 70\right.$ to 74 , where $\mathrm{Mg}^{*}=100 \times \mathrm{Mg} /(\mathrm{Mg}+$ Fe) in moles; Fig. 5). Orthopyroxene phenocrysts are also relatively homogeneous in composition ( $\mathrm{Mg}^{*} 64$ to 68), although some exhibit high $\mathrm{Mg}^{*}(>70)$. Orthopyroxene and clinopyroxene phenocrysts often show reverse zoning in

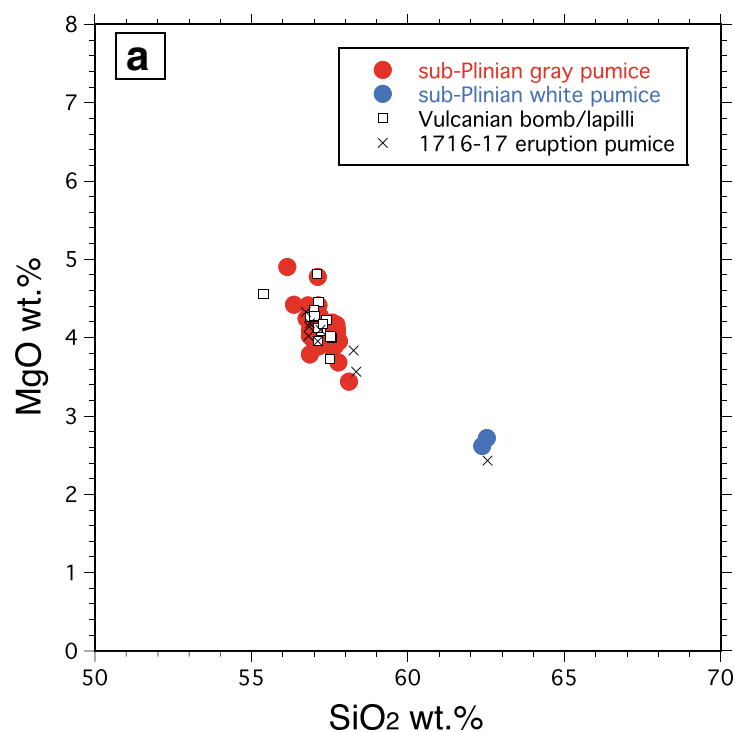

Fig. 3 Bulk rock compositions of gray and white pumices ejected from the January 26-27, 2011, sub-Plinian eruptions and bombs or lapilli ejected from Vulcanian eruptions between January 28 and February 14.
$\mathrm{Mg}^{*}$ within rims approximately $10 \mu \mathrm{m}$ in width. The twopyroxene thermometer of the QUILF software (Lindsley and Frost 1992) was used to determine that most pairs, including core-core and rim-rim, indicate equilibrium temperatures of 900-1,000 ${ }^{\circ} \mathrm{C}$, although some rim-rim pairs show higher temperatures at $1,050-1,150{ }^{\circ} \mathrm{C}$. Olivine phenocrysts show homogeneous cores (Mg* 75-80; Fig. 6) and normal zoning near the rims up to several tens of microns (Fig. 7), with or without reaction rims of orthopyroxene.

Phenocryst aggregates are common in all types of pumice, and their mineral assemblage is typically plagioclase + orthopyroxene + clinopyroxene + magnetite + ilmenite. Neither high-Ca (approximately An 90) plagioclase nor olivine is included in such aggregates.

Melt inclusions in phenocrysts (Saito et al. 2011; Saito 2012) are basaltic andesite $\left(\mathrm{SiO}_{2} 54 \mathrm{wt} \%\right)$ in olivine and rhyolite $\left(\mathrm{SiO}_{2} 75 \mathrm{wt} \%\right)$ in low-Ca plagioclase and in pyroxene. Dacitic $\left(\mathrm{SiO}_{2} 68 \mathrm{wt} \%\right)$ melt inclusions are also observed in pyroxene.

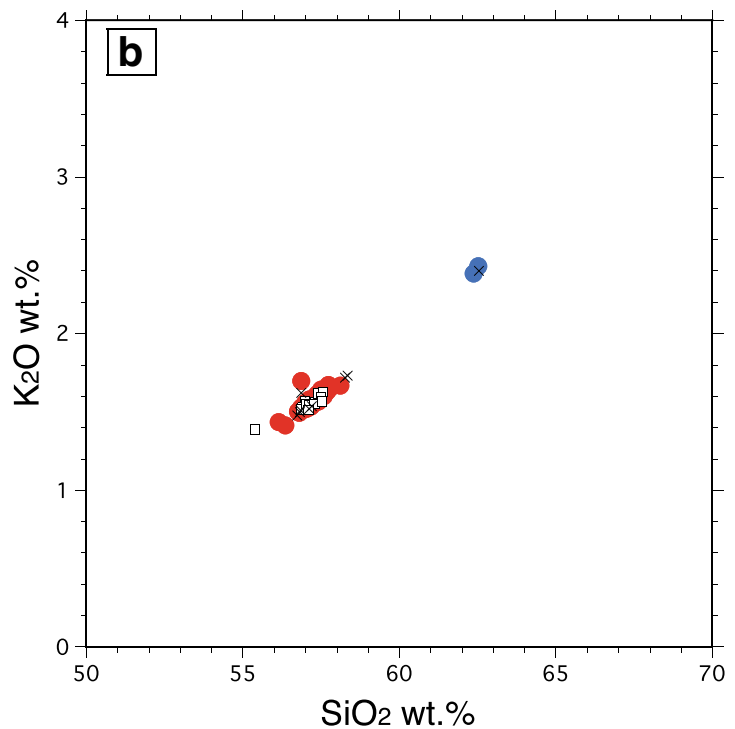

Those of pumices ejected from the 1716-1717 eruptions are also shown for comparison: a $\mathrm{SiO}_{2}$ versus $\mathrm{MgO}$; b $\mathrm{SiO}_{2}$ versus $\mathrm{K}_{2} \mathrm{O}$ 

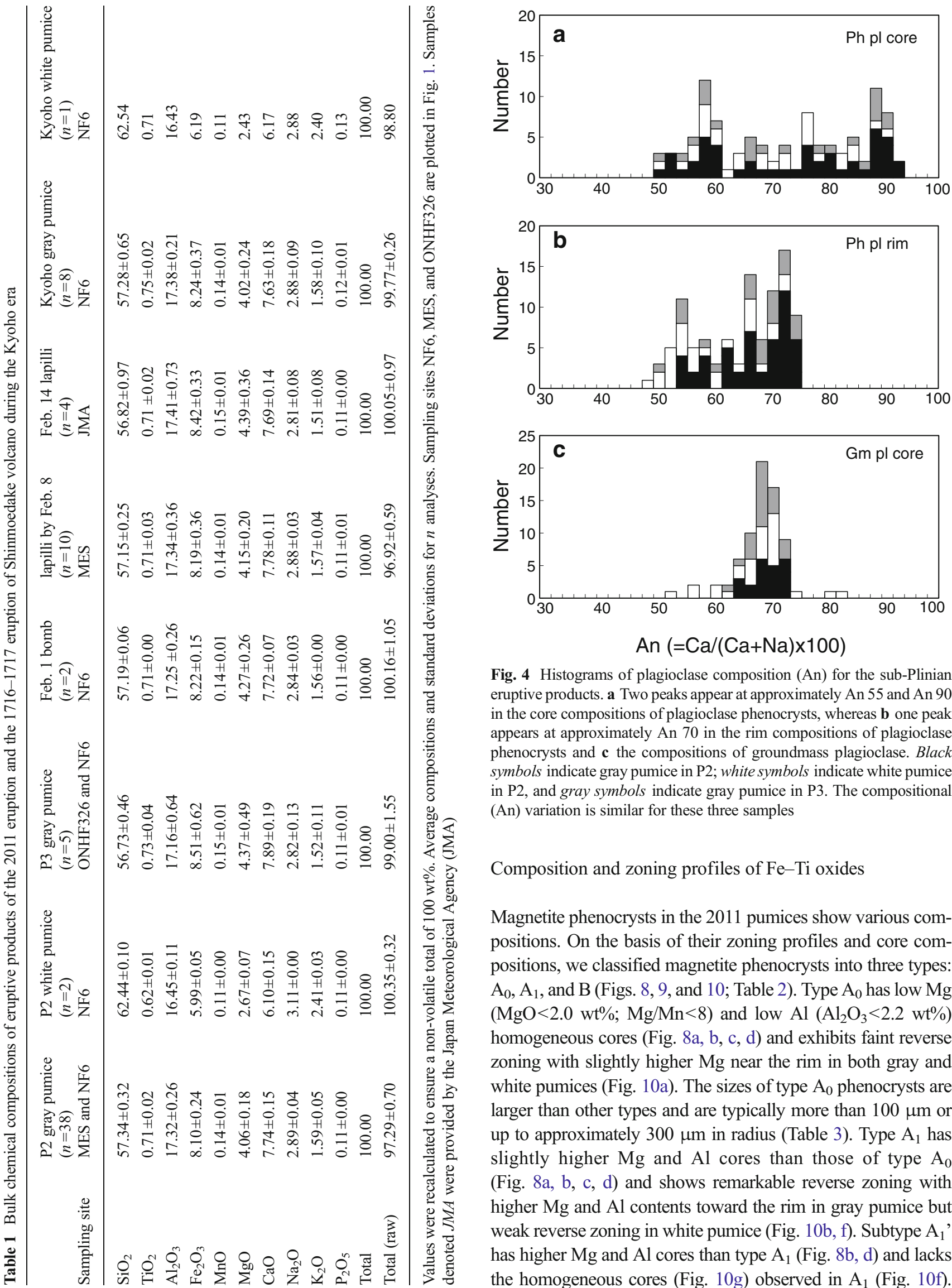

Fig. 4 Histograms of plagioclase composition (An) for the sub-Plinian eruptive products. a Two peaks appear at approximately An 55 and An 90 in the core compositions of plagioclase phenocrysts, whereas b one peak appears at approximately An 70 in the rim compositions of plagioclase phenocrysts and $\mathbf{c}$ the compositions of groundmass plagioclase. Black symbols indicate gray pumice in $\mathrm{P} 2$; white symbols indicate white pumice in P2, and gray symbols indicate gray pumice in P3. The compositional (An) variation is similar for these three samples

Composition and zoning profiles of $\mathrm{Fe}-\mathrm{Ti}$ oxides

Magnetite phenocrysts in the 2011 pumices show various compositions. On the basis of their zoning profiles and core compositions, we classified magnetite phenocrysts into three types: $\mathrm{A}_{0}, \mathrm{~A}_{1}$, and $\mathrm{B}$ (Figs. 8, 9, and 10; Table 2). Type $\mathrm{A}_{0}$ has low $\mathrm{Mg}$ $(\mathrm{MgO}<2.0 \mathrm{wt} \% ; \mathrm{Mg} / \mathrm{Mn}<8)$ and low $\mathrm{Al}\left(\mathrm{Al}_{2} \mathrm{O}_{3}<2.2 \mathrm{wt} \%\right)$ homogeneous cores (Fig. 8a, b, c, d) and exhibits faint reverse zoning with slightly higher $\mathrm{Mg}$ near the rim in both gray and white pumices (Fig. 10a). The sizes of type $\mathrm{A}_{0}$ phenocrysts are larger than other types and are typically more than $100 \mu \mathrm{m}$ or up to approximately $300 \mu \mathrm{m}$ in radius (Table 3 ). Type $A_{1}$ has slightly higher $\mathrm{Mg}$ and $\mathrm{Al}$ cores than those of type $\mathrm{A}_{0}$ (Fig. 8a, b, c, d) and shows remarkable reverse zoning with higher $\mathrm{Mg}$ and $\mathrm{Al}$ contents toward the rim in gray pumice but weak reverse zoning in white pumice (Fig. 10b, f). Subtype $A_{1}$, has higher $\mathrm{Mg}$ and $\mathrm{Al}$ cores than type $\mathrm{A}_{1}$ (Fig. 8b, d) and lacks the homogeneous cores (Fig. 10g) observed in $\mathrm{A}_{1}$ (Fig. 10f). 

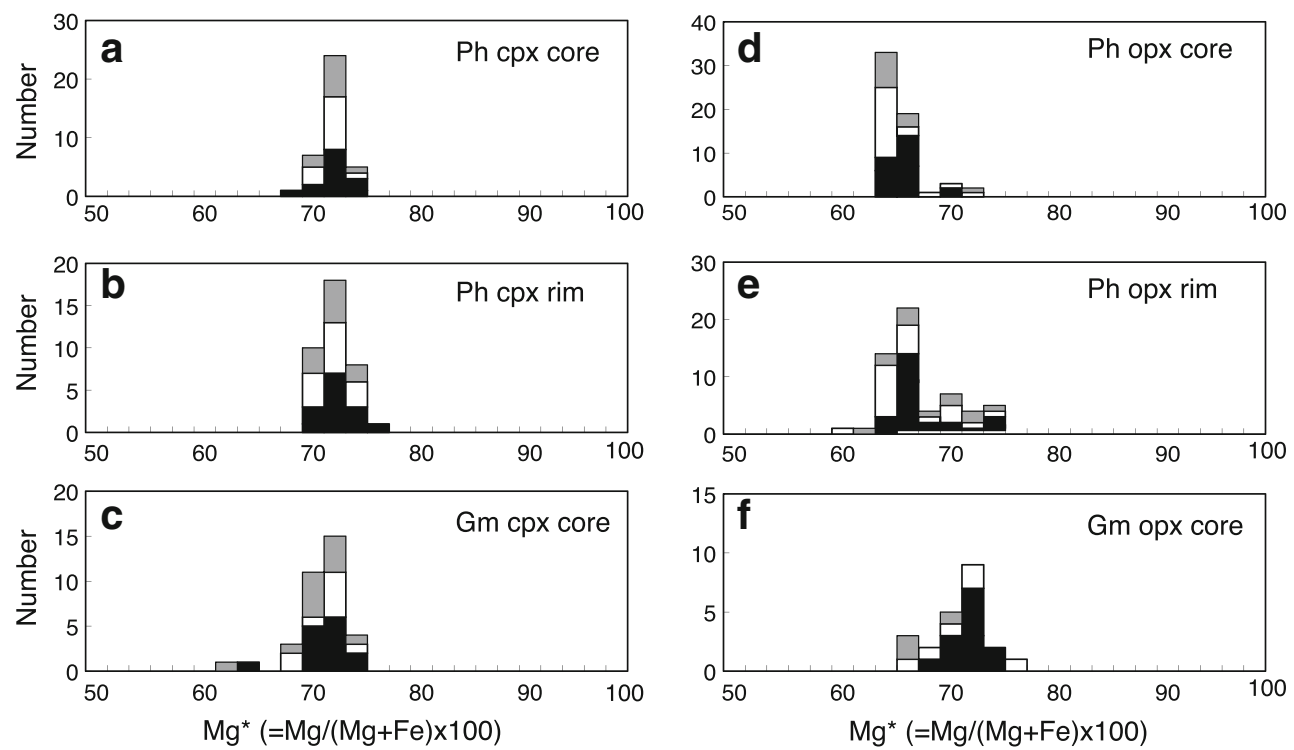

Fig. 5 Histograms of $\mathbf{a}-\mathbf{c}$ clinopyroxene and $\mathbf{d}-\mathbf{f}$ orthopyroxene composition $\left(\mathrm{Mg}^{*}\right)$ for the sub-Plinian eruptive products. Compositions of core and rim of phenocrysts and groundmass are relatively homogeneous with $\mathrm{Mg} *$ 70-74 for clinopyroxene and $\mathrm{Mg}^{*}$ 64-68 for orthopyroxene, although some orthopyroxene phenocrysts have high $\mathrm{Mg}^{*}(>70)$. a Core
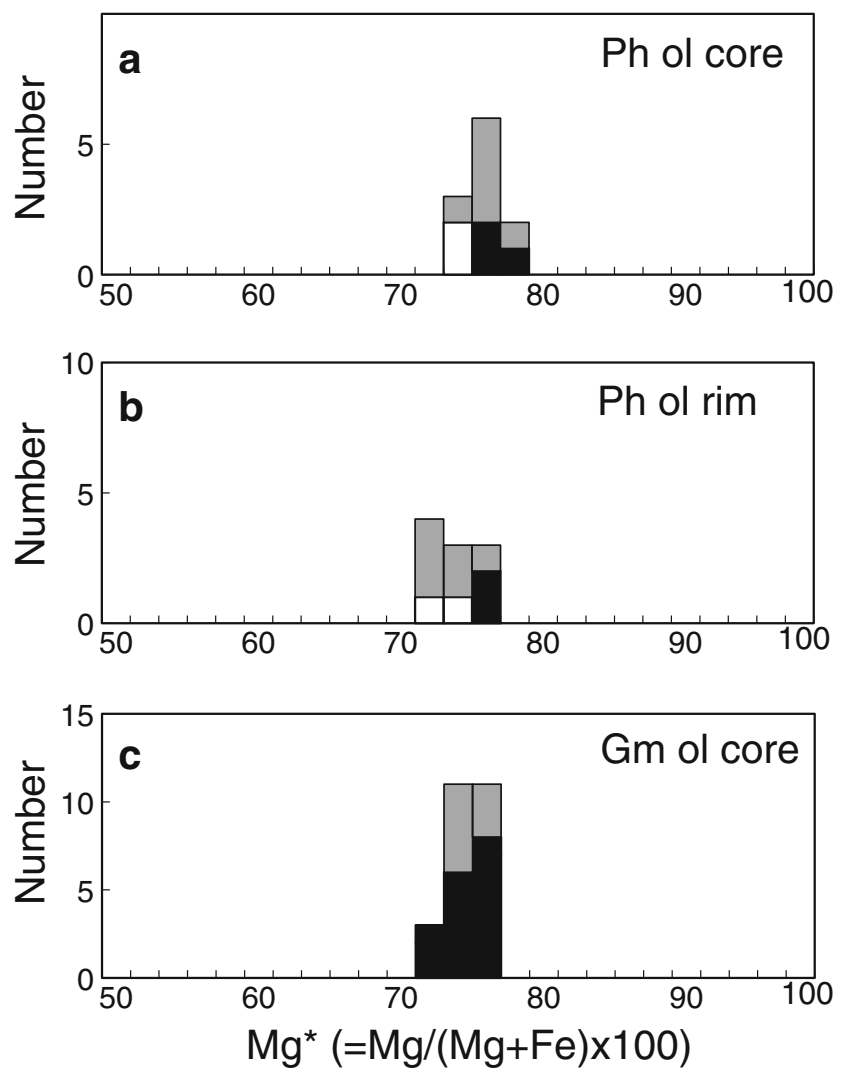

Fig. 6 Histograms of olivine composition $\left(\mathrm{Mg}^{*}\right)$ for the sub-Plinian eruptive products. Compositions of olivine phenocrysts and groundmass are homogeneous $(\mathrm{Mg} * 75-80)$. a Core of olivine phenocrysts; $\mathbf{b}$ rim of olivine phenocrysts; c groundmass olivine. Symbols (black, white, and gray) are the same as those in Fig. 4. Groundmass olivine was not detected in white pumice

of clinopyroxene phenocrysts; $\mathbf{b}$ rim of clinopyroxene phenocrysts; $\mathbf{c}$ groundmass clinopyroxene; $\mathbf{d}$ core of orthopyroxene phenocrysts; e rim of orthopyroxene phenocrysts; f groundmass orthopyroxene. Symbols (black, white, and gray) indicate the same as those in Fig. 4

The core compositions gradually change from type $A_{1}$ to type $\mathrm{A}_{1}{ }^{\prime}$, and the rim compositions of these two types nearly overlap (Fig. 8b, d). The sizes of type- $\mathrm{A}_{1}$ ' magnetite are smaller than approximately $70 \mu \mathrm{m}$ in radius (Table 3 ); thus, they are identified as microphenocrysts. Type B has a distinctly higher Ti (XUsp $>0.32$, where XUsp is mole fraction of Usp component) content than that in all types and a higher $\mathrm{Al}$ composition than that of type $\mathrm{A}_{1}$ (Fig. 8b, d). Subtype B' has the highest $\mathrm{Mg}$ $(\mathrm{MgO}>3.0 \mathrm{wt} \% ; \mathrm{Mg} / \mathrm{Mn}>15)$ and $\mathrm{Al}\left(\mathrm{Al}_{2} \mathrm{O}_{3}>3.0 \mathrm{wt} \%\right)$ core compositions (Fig. 8b, d) and lacks the homogeneous cores (Fig. 10h) observed in type B (Fig. 10g). The sizes of typeB' magnetite are smaller at approximately $25-40 \mu \mathrm{m}$ in radius; thus, they are identified as microphenocrysts.

The rim composition $\left(\mathrm{MgO}, \mathrm{Al}_{2} \mathrm{O}_{3}\right)$ of type $\mathrm{A}_{0}$ is similar to the core composition of type $\mathrm{A}_{1}$ (Fig. 8a, b, c, d). The rim composition of type $A_{1}$ is similar to the core compositions of type $A_{1}$ ' and type B' (Fig. 8b, d). The rim compositions of types $\mathrm{A}_{1}$ ' and $\mathrm{B}$ are similar to the core composition of type $\mathrm{B}$ ' (Fig. 8b, d). The rim composition of type $\mathrm{B}^{\prime}$ is higher in $\mathrm{Al}_{2} \mathrm{O}_{3}$ and lower in XUsp (Fig. 8b, d), thus we propose a hidden end member, $\mathrm{X}$, beyond the rim compositions. Type $\mathrm{A}_{1}$ is the most abundant. Apparent ratios of types $\mathrm{A}_{0}, \mathrm{~A}_{1}$, and $\mathrm{B}$ are $14 \%$, $62 \%$, and $24 \%$ in the gray pumice and $50 \%, 50 \%$, and $0 \%$ in white pumice, respectively, for $\mathrm{P} 2$.

Ilmenite phenocrysts have no $(\mathrm{P} 2)$ or thin $(\mathrm{P} 3)$ reaction rims of magnetite that are several microns in thickness. Two types of ilmenite were identified on the basis of core compositions (Fig. 8e, f). One has low $\mathrm{Mg}(\mathrm{MgO}<3.0 \mathrm{wt} \%$; $\mathrm{Mg} / \mathrm{Mn}<13)$, low $\mathrm{Al}\left(\mathrm{Al}_{2} \mathrm{O}_{3}<0.35 \mathrm{wt} \%\right)$, and high XIlm cores, and the other has high $\mathrm{Mg}(\mathrm{MgO}>3.5 \mathrm{wt} \% ; \mathrm{Mg} / \mathrm{Mn}>15)$, high $\mathrm{Al}\left(\mathrm{Al}_{2} \mathrm{O}_{3}>\right.$ 

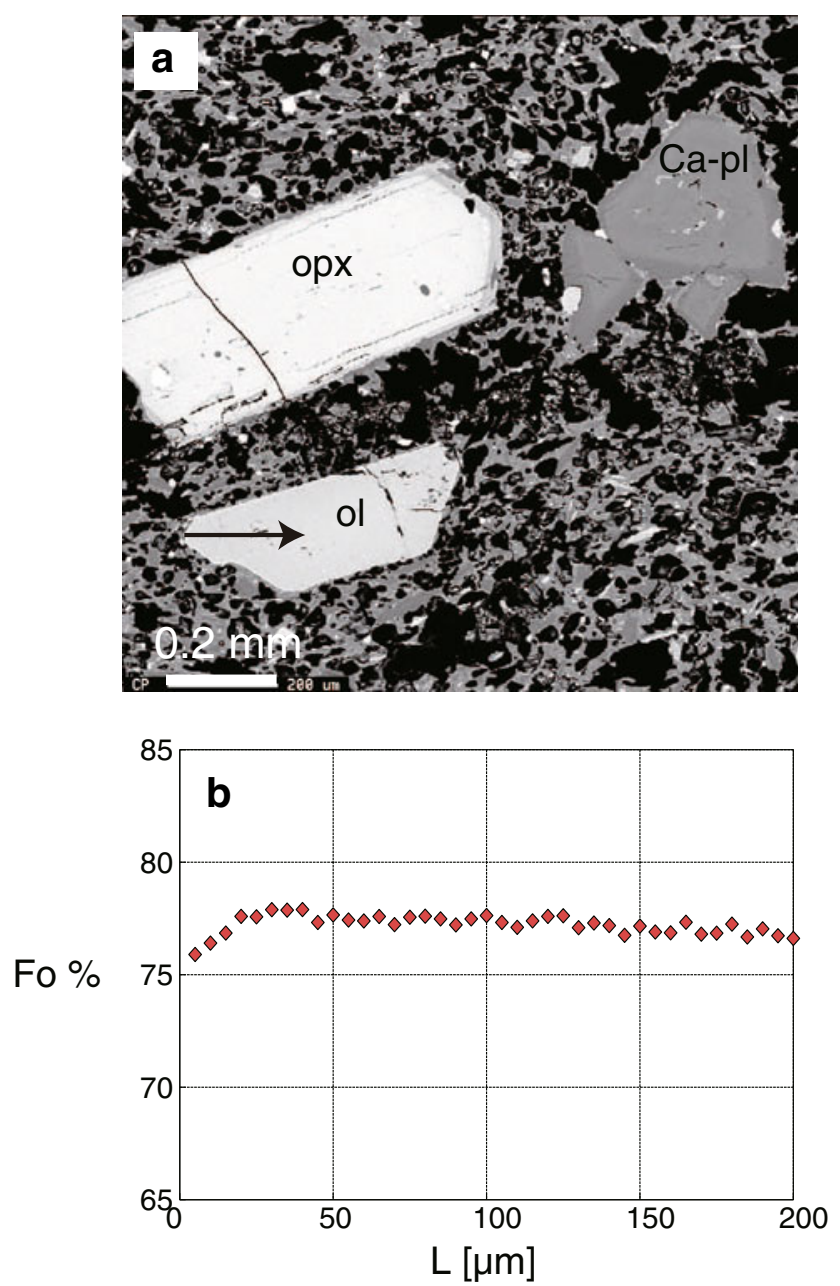

Fig. 7 a Back-scattered electron image of gray pumice from the January 26-27, 2011, eruption: ol, olivine; opx, orthopyroxene; $C a-p l$, calcic plagioclase (An 90). The arrow indicates zoning profile position in (b). Opx has an Mg-rich (dark) rim, and calcic plagioclase has an An-poor (dark) rim. Both widths are less than several tens of microns. b Zoning profile (forsterite component, $F_{O}$ ) of the olivine phenocryst in (a). Horizontal axis $(L)$ is the distance from the rim. Fo $\left(\mathrm{Mg}^{*}\right)$ decreases toward the rim within several tens of microns. After Saito (2012, in preparation)

$0.4 \mathrm{wt} \%$ ), and low XIlm cores, where XIlm is mole fraction of ilmenite (Ilm) component. According to Bacon and Hirschmann (1988), $\mathrm{Mg} / \mathrm{Mn}$ of equilibrium magnetite for the first type of ilmenite $(\mathrm{Mg} / \mathrm{Mn}=10$ to 13$)$ is approximately 7-9, which corresponds to type $A_{0}$ magnetite (Fig. 8a, b). Similarly, equilibrium magnetite for the second type of ilmenite $(\mathrm{Mg} / \mathrm{Mn}=15-19)$ is approximately $10-13$, which corresponds to type $A_{1}$ magnetite. Thus, we consider the first type of ilmenite to be type $A_{0}$ and the second to be type $A_{1}$. No ilmenite was determined to be in equilibrium with type $\mathrm{B}$ magnetite.

Types $\mathrm{A}_{0}$ and $\mathrm{A}_{1}$ ilmenite with no reaction rims show faint or no reverse zoning (Figs. 8e, f and 11a, b). Near the contacts between type $A_{1}$ magnetite and type $A_{1}$ ilmenite grains in aggregates, compositions significantly change toward the contacts (Fig. 11c), that is, XUsp and $\mathrm{MgO}$ in magnetite significantly increase and $\mathrm{Al}_{2} \mathrm{O}_{3}$ in magnetite decreases toward the contact.

\section{Fe-Ti oxide geothermometry}

We estimated magmatic temperatures by using the magnetiteilmenite geothermometer described by Andersen and Lindsley (1985) with Stormer (1983). According to a comparison of four representative methods (Blundy and Cashman 2008) in addition to the recommendation of Gardner et al. (1995), we judged that the method by Andersen and Lindsley (1985) with Stormer (1983) is the best choice for a temperature range in the present study because it gave the smallest average absolute deviation $\left( \pm 33^{\circ} \mathrm{C}\right.$ ); other methods gave more scattered or biased results (Fig. 13 of Blundy and Cashman 2008). Ilmenite phenocrysts often form aggregates with types $A_{0}$ and $A_{1}$ magnetite. From the cores of magnetite and ilmenite, we obtained $875^{\circ} \mathrm{C}$ and $\log \mathrm{fO}_{2}=-11.4$ for type $\mathrm{A}_{0}$ and $889^{\circ} \mathrm{C}$ and $\log \mathrm{fO}_{2}=-11.1$ for type $\mathrm{A}_{1}$, respectively. From the points adjacent to (<approximately $5 \mu \mathrm{m}$ ) the contact between type $A_{1}$ magnetite and type $\mathrm{A}_{1}$ ilmenite grains in aggregates, we obtained temperatures of 933-966 ${ }^{\circ} \mathrm{C}$ and $\log \mathrm{fO}_{2}=-10.6$ to -10.1 . These estimates are consistent with those by two-pyroxene thermometry, which is approximately $900-1,000{ }^{\circ} \mathrm{C}$.

\section{Discussion 1: magma-mixing processes}

\section{End members of magma mixing}

Two types of magma were identified on the basis of silicate mineral compositions such as bimodal distribution in plagioclase compositions (approximately An 55 and An 90; Saito et al. 2011) and mineral assemblage of phenocryst aggregates. One is a low-temperature silicic magma that contains low-Ca (approximately An 55) plagioclase, orthopyroxene, clinopyroxene, magnetite, and ilmenite with a rhyolitic melt. The other is a high-temperature mafic magma that contains high-Ca (approximately An 90) plagioclase and olivine with a basaltic-andesitic melt. Clearly, the two contrasting types of magma were mixed prior to the sub-Plinian eruption of Shinmoedake. The intermediate composition (An 70) of plagioclase rims and groundmass plagioclase represents conditions after the magma mixing.

Magnetite data also provided evidence of mixing between high- and low-temperature magmas, such as the reverse zoning apparent in most of the magnetite phenocrysts and the increase in temperature from the cores to the contacts between magnetite and ilmenite. The temperatures from the cores of magnetite and ilmenite $\left(875-889{ }^{\circ} \mathrm{C}\right)$ and those from the contacts between magnetite and ilmenite $\left(933-966^{\circ} \mathrm{C}\right)$ represent the conditions before and just after the magma mixing, respectively. The reverse zoning was formed by diffusion rather than growth because the widths of zoning differed among the elements 

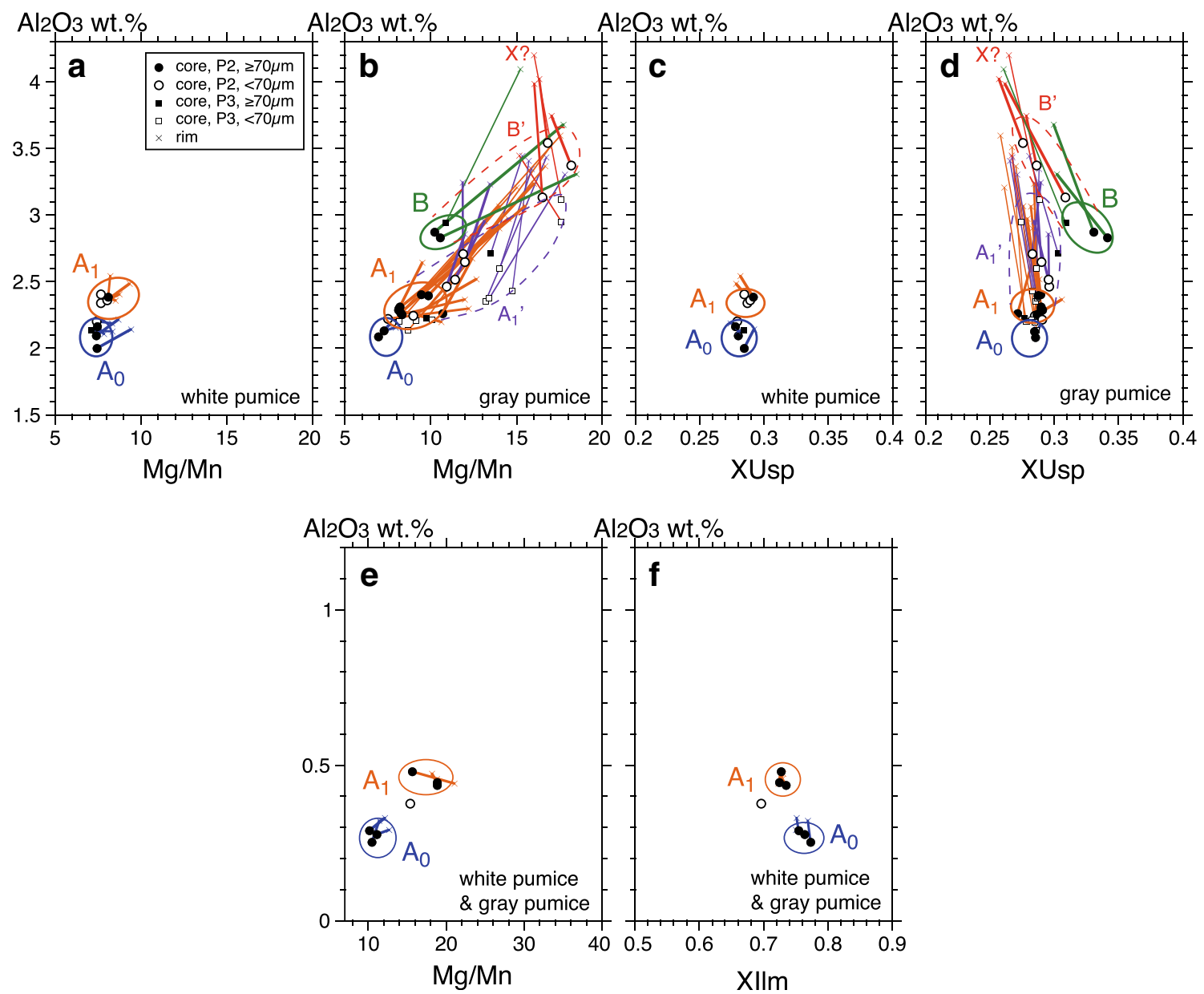

Fig. 8 Chemical compositions of magnetite and ilmenite phenocrysts. Three types, $\mathrm{A}_{0}, \mathrm{~A}_{1}$, and $\mathrm{B}$, with subtypes of $\mathrm{A}_{1}$ ' and $\mathrm{B}$ ', were recognized on the basis of core compositions and zoning patterns. Closed and open symbols denote phenocrysts (radius $\geq 70 \mu \mathrm{m}$ ) and microphenocrysts (radius $<70 \mu \mathrm{m}$ ), respectively. Circles and squares denote P2 and P3, respectively. Crosses denote rim compositions. Each core and rim of a phenocryst or microphenocryst is connected by a tie line. All but one

(Fig. 10). The absence or thin appearances of reverse-zoned rims of pyroxene or reaction rims of ilmenite also confirm that the magma mixing occurred just prior to the eruptions.

On the basis of magnetite compositions, the three types of magnetite contribute to discussions of more detailed processes. First, we consider that type $\mathrm{A}_{0}$ magnetite represents the lowtemperature end member of the magma-mixing process because this type has the lowest $\mathrm{Mg}$ and $\mathrm{Al}$ contents and homogeneous cores, indicating stable conditions prior to magma mixing. In addition, type $\mathrm{A}_{0}$ was little affected by heating and showed reverse zoning due to magma mixing. The origin of type $A_{1}$ is similar to that of type $\mathrm{A}_{0}$ but originated from a portion in which the effects of magma mixing were more significant. The variable rim compositions of type $A_{1}$ suggest local heterogeneity in melt compositions and temperature during the magma mixing. We also consider type $A_{1}$ ' magnetite to be of the same origin as type $A_{1}$ magnetite for the following reasons: Core compositions (radius $=74 \mu \mathrm{m}$ ) of type $\mathrm{A}_{1}$ ' and $\mathrm{B}^{\prime}$ magnetite are microphenocrysts, and their compositions are scattered because of chemical diffusion. a $\mathrm{Mg} / \mathrm{Mn}$ and $\mathrm{Al}_{2} \mathrm{O}_{3}$ of magnetite in white pumice or in a white band of banded pumice; $\mathbf{b} \mathrm{Mg} / \mathrm{Mn}$ and $\mathrm{Al}_{2} \mathrm{O}_{3}$ of magnetite in gray pumice; $\mathbf{c}$ XUsp and $\mathrm{Al}_{2} \mathrm{O}_{3}$ of magnetite in white pumice or in a white band of banded pumice; d XUsp and $\mathrm{Al}_{2} \mathrm{O}_{3}$ of magnetite in gray pumice; e $\mathrm{Mg} / \mathrm{Mn}$ and $\mathrm{Al}_{2} \mathrm{O}_{3}$ of ilmenite; f XIlm and $\mathrm{Al}_{2} \mathrm{O}_{3}$ of ilmenite

change from types $A_{1}$ to $A_{1}$ ' gradually; the core composition of type $A_{1}$ ' magnetite are between those of the core and rim of type $\mathrm{A}_{1}$ magnetite (Fig. 8); and no homogeneous $\mathrm{Al}_{2} \mathrm{O}_{3}$ core is present in type $A_{1}$ ' magnetite. These features indicate that type $A_{1}$ ' magnetite was originally type $A_{1}$ magnetite that experienced significant diffusion to the core. The small sizes of type $A_{1}$ ' grains (Table 3 ) also support this interpretation. An additional possibility is that type $\mathrm{A}_{1}$ ' magnetite is actually type $\mathrm{A}_{1}$ magnetite; however, its true center was not included in the thin section. This possibility, however, can be disproved because the sectioning effect on type $A_{1}$ magnetite (Fig. 10b, f) results in a zoning profile that shows a decrease in $\mathrm{MgO}$ from the rim to core with an $\mathrm{Al}_{2} \mathrm{O}_{3}$ decrease. Zoning profiles of type $\mathrm{A}_{1}$ ' magnetite, however, show that $\mathrm{MgO}$ is nearly flat (Fig. 10c) with decreasing $\mathrm{Al}_{2} \mathrm{O}_{3}$ from rim to core (Fig. $10 \mathrm{~g}$ ).

Despite having the highest $\mathrm{MgO}$ and $\mathrm{Al}_{2} \mathrm{O}_{3}$ contents, type $\mathrm{B}$ ' magnetite is not a representative high-temperature end 

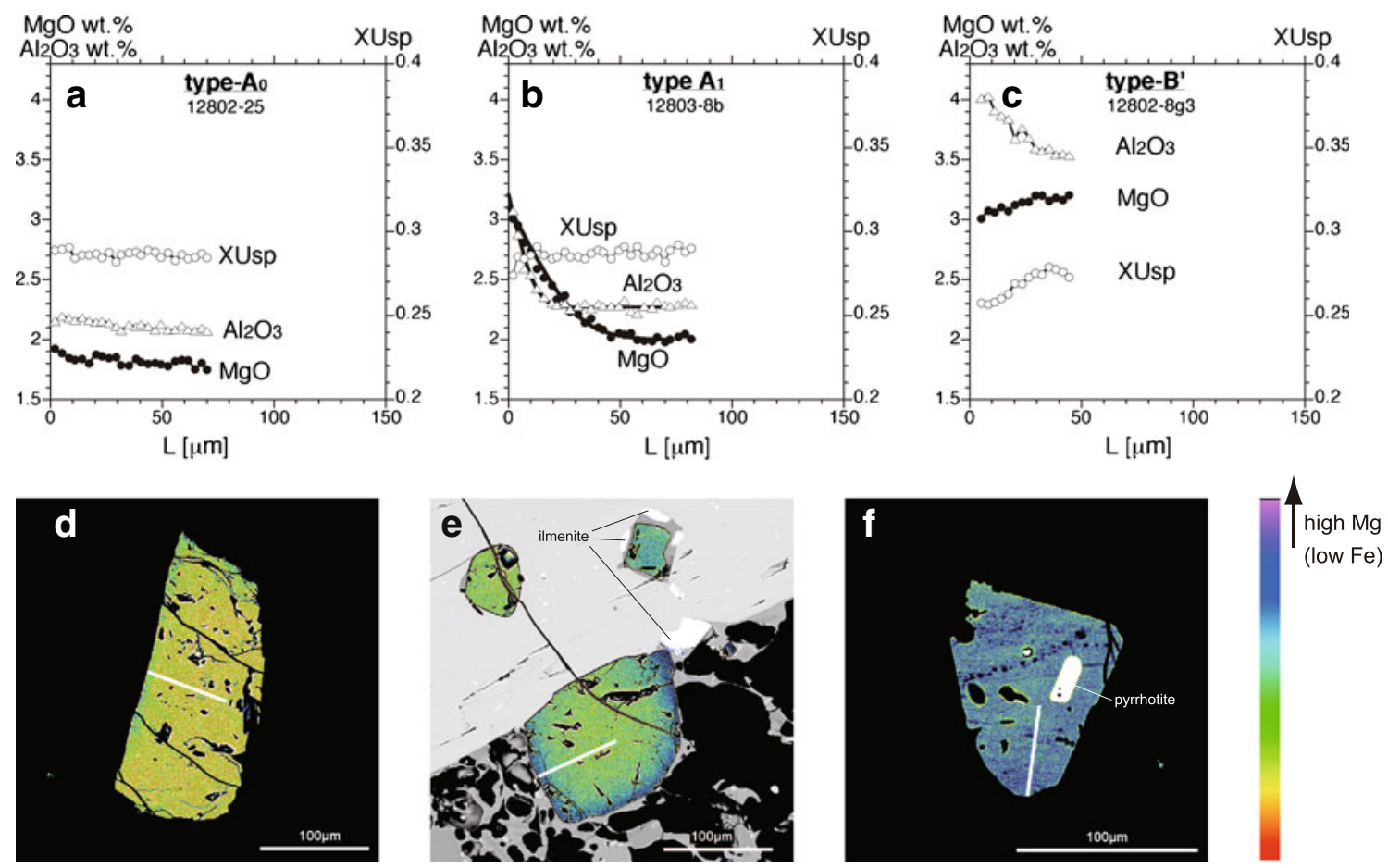

Fig. 9 a-c Representative zoning profile of types $A_{0}, A_{1}$, and B' magnetite in the gray pumice of the 2011 sub-Plinian eruptions of Shinmoedake volcano. Horizontal axis shows the distance from the rim. Thick curves in (b) are examples of the fitting calculation. d-f Pseudo-colored back-

scattered electron images of the magnetite grains corresponding to $\mathbf{a}-\mathbf{c}$, respectively. White lines indicate positions of the line profiles. Magnetite inclusion that was isolated from the melt (upper left of (e)) is not zoned and retains the core composition prior to magma mixing

member because it also shows reverse zoning with an increase in $\mathrm{Al}_{2} \mathrm{O}_{3}$ toward the rim (Figs. 8 and 10), indicating that type B' magnetite was also heated by high-temperature magma. Thus, no magnetite is present in the high-temperature magma that contained high-Ca plagioclase and olivine. We consider that type B' magnetite originated from mixed magma that was formed between low- and high-temperature end members because its core compositions are similar to the rim compositions of types $A_{1}, A_{1}$, and $B$.

Although its XUsp is much higher than other types, we consider type $B$ to be an intermediate between types $A_{1}$ and $B$ ' on the basis of the following observations: $\mathrm{Al}_{2} \mathrm{O}_{3}$ contents of the cores of type $B$ magnetite are between type $A_{1}\left(A_{1}{ }^{\prime}\right)$ and type B' magnetite (Fig. 8b, d); common or continuous conditions between types B and B' magnetite were indicated by the common negative correlation between XUsp and $\mathrm{Al}_{2} \mathrm{O}_{3}$ (Fig. 8d) and the common zoning pattern in XUsp of a decrease toward the rim (Fig. 10k, 1); and $\mathrm{Mg} / \mathrm{Mn}$ of the cores and the zoning pattern of $\mathrm{MgO}$ of type $\mathrm{B}$ magnetite are similar to those of type $A_{1}$ magnetite (Figs. $8 b$ and $\left.10 b, c\right)$. Thus, type $B$ magnetite has characteristics intermediate between types $A_{1}$ and $\mathrm{B}$ ' magnetite. When we arrange the types of magnetite in ascending order of $\mathrm{Al}_{2} \mathrm{O}_{3}$ as types $\mathrm{A}_{0}, \mathrm{~A}_{1}, \mathrm{~A}_{1}$ ', $\mathrm{B}$, and $\mathrm{B}$ ', the values of XUsp are nearly constant from type $A_{0}$ to type $A_{1}$ ' before abruptly increasing between types $\mathrm{A}_{1}$ ' and $\mathrm{B}$ and gradually decreasing to type B' (Fig. 8d). Because only types $\mathrm{A}_{0}$ and $\mathrm{A}_{1}$ magnetite coexist with ilmenite, we consider that the abrupt jump of XUsp, showing an increase in Ti content in magnetite, corresponds to the vanishing point or stability limit of ilmenite; below this point, XUsp is buffered and is nearly constant with the low value of 0.28 to 0.29 , owing to the presence of ilmenite. The negative correlation between $\mathrm{Al}_{2} \mathrm{O}_{3}$ and XUsp of types $\mathrm{B}$ and B' magnetite can be explained by elemental partitioning of $\mathrm{Al}$ and $\mathrm{Ti}$ in magnetite (Lindsley 1991).

We here consider four types of magma, $A_{0}, A_{1}, B$, and $X$, which originally contained types $A_{0}, A_{1}\left(+A_{1}{ }^{\prime}\right), B(+B$ '), and no magnetite, respectively (Fig. 12; Table 4). Magma $A_{0}$ was the low-temperature end-member silicic magma and contained low-Ca (approximately An 55) plagioclase, orthopyroxene, clinopyroxene, type $A_{0}$ magnetite, and type $A_{0}$ ilmenite. Magma $A_{1}$ was similar to magma $A_{0}$ but was significantly heated just prior to the eruption, as evidenced by the significant reverse zoning of type $A_{1}$ magnetite; this is in contrast to magma $\mathrm{A}_{0}$, which was not significantly heated and preserved the characteristics of the low-temperature end-member magma. Magma $\mathrm{A}_{0}$ was likely mushy magma because its crystal content should have been higher than 28 vol\%. Magma $\mathrm{X}$ is the high-temperature mafic end-member magma and contains high-Ca (approximately An 90) plagioclase and olivine. Magma B is intermediate magma formed by further heating of magma $A_{1}$ and mixing between low-temperature $\left(\mathrm{A}_{0}\right.$ or $\left.\mathrm{A}_{1}\right)$ and high-temperature $(\mathrm{X})$ magmas.

According to the bulk-rock and melt-inclusion compositions of the eruptive products, we consider magma $\mathrm{A}_{0}$ and 

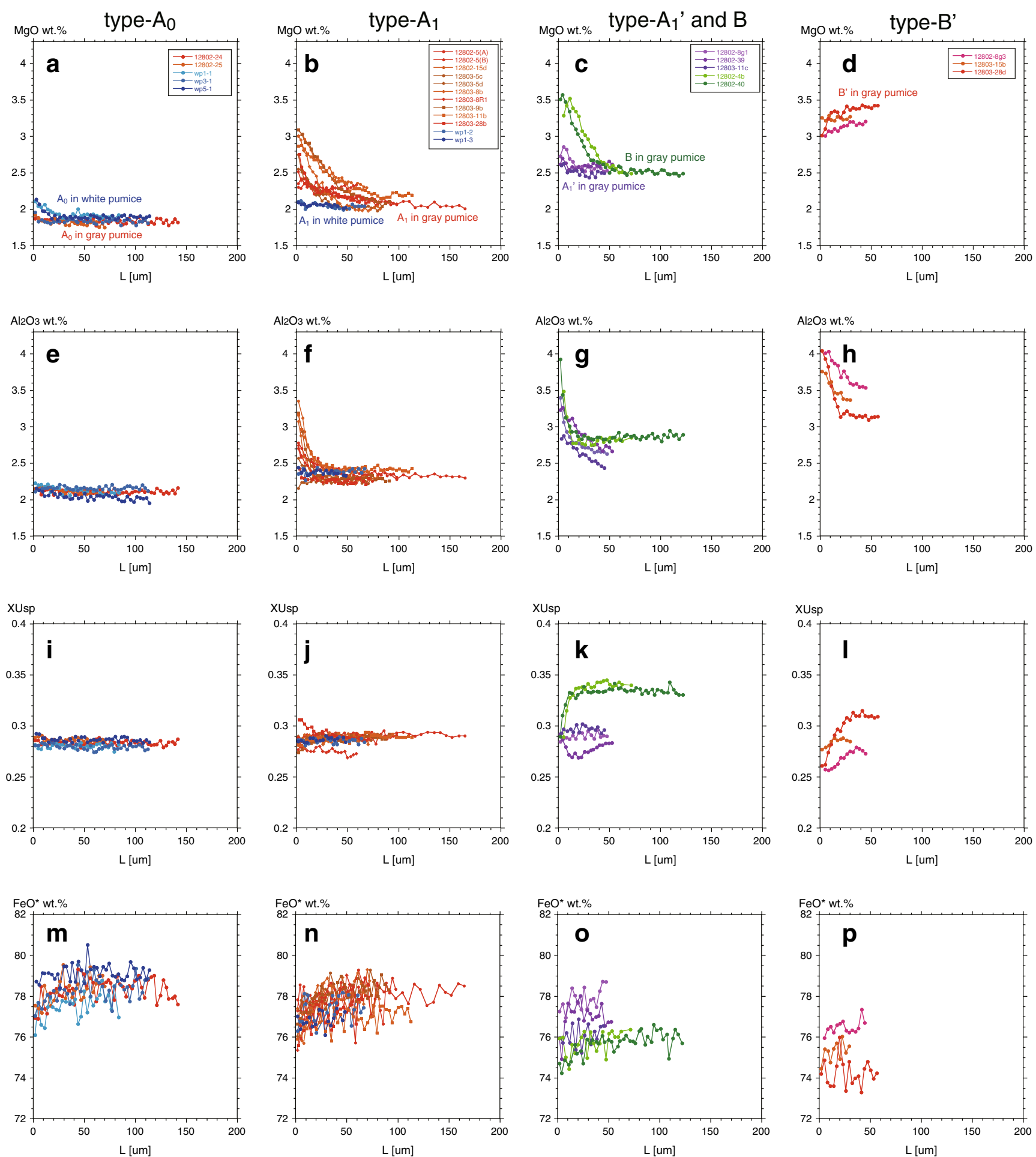

Fig. 10 Zoning profiles of analyzed magnetite grains. $\mathbf{a}-\mathbf{d ~} \mathrm{MgO} ; \mathbf{e}-\mathbf{h ~} \mathrm{Al}_{2} \mathrm{O}_{3} ; \mathbf{i}-\mathbf{l} \mathrm{XUsp} ; \mathbf{m}-\mathbf{p ~ F e O}$ (raw data). Three of these profiles, 12802-25, 12803-8b, and 12802-8g3, are also shown in Fig. 9

magma $\mathrm{X}$ to be dacite $\left(\mathrm{SiO}_{2} \geq 63 \mathrm{wt} \%\right)$ and basalt or basaltic andesite $\left(\mathrm{SiO}_{2} \leq 54 \mathrm{wt} \%\right)$, respectively (Table 4). Magmas $\mathrm{A}_{1}$ and $\mathrm{B}$ were not end members but were modified or mixed magma. Magma B in particular may reflect local conditions because of its low frequency of appearance.
Neither type of magma erupted solely; rather, their eruptions were mixed. White pumice (andesitic dacite) was comprised of magma $A_{0}+$ magma $A_{1}$. Gray pumice (andesite) was comprised of mainly magma $A_{1}$ with small contributions of magmas $\mathrm{B}, \mathrm{X}$, and $\mathrm{A}_{0}$. 
Table 2 Chemical compositions of cores and rims of magnetite grains analyzed for the zoning profiles

\begin{tabular}{|c|c|c|c|c|c|c|c|c|c|c|}
\hline Grain ID & Type & $\mathrm{c} / \mathrm{r}$ & $\mathrm{TiO}_{2}$ & $\mathrm{Al}_{2} \mathrm{O}_{3}$ & $\mathrm{Fe}_{2} \mathrm{O}_{3}$ & $\mathrm{FeO}$ & $\mathrm{MnO}$ & $\mathrm{MgO}$ & XUsp & $\mathrm{Mg} / \mathrm{Mn}$ \\
\hline \multicolumn{11}{|l|}{ Gray pumice } \\
\hline \multirow[t]{2}{*}{$12802-24$} & \multirow[t]{2}{*}{$\mathrm{A}_{0}$} & Core & 9.68 & 2.13 & 48.61 & 37.22 & 0.44 & 1.84 & 0.285 & 7.3 \\
\hline & & Rim & 9.71 & 2.15 & 48.43 & 37.23 & 0.42 & 1.88 & 0.286 & 8.0 \\
\hline \multirow[t]{2}{*}{$12802-25$} & \multirow[t]{2}{*}{$\mathrm{A}_{0}$} & Core & 9.70 & 2.08 & 48.52 & 37.36 & 0.45 & 1.77 & 0.285 & 7.0 \\
\hline & & Rim & 9.82 & 2.17 & 48.21 & 37.31 & 0.44 & 1.90 & 0.289 & 7.6 \\
\hline \multirow[t]{2}{*}{$12802-5$} & \multirow[t]{2}{*}{$\mathrm{A}_{1}$} & Core & 9.85 & 2.31 & 48.22 & 37.09 & 0.44 & 2.03 & 0.290 & 8.2 \\
\hline & & Rim & 9.40 & 2.74 & 48.61 & 35.99 & 0.40 & 2.39 & 0.279 & 10.5 \\
\hline \multirow[t]{2}{*}{$12802-15 d$} & \multirow[t]{2}{*}{$\mathrm{A}_{1}$} & Core & 9.76 & 2.39 & 48.43 & 36.60 & 0.41 & 2.32 & 0.287 & 9.8 \\
\hline & & Rim & 9.55 & 3.24 & 47.99 & 35.64 & 0.34 & 3.02 & 0.285 & 16.0 \\
\hline \multirow[t]{2}{*}{$12803-5 \mathrm{c}$} & \multirow[t]{2}{*}{$\mathrm{A}_{1}$} & Core & 9.87 & 2.29 & 48.09 & 37.12 & 0.44 & 2.01 & 0.291 & 8.1 \\
\hline & & Rim & 9.76 & 2.20 & 48.73 & 36.23 & 0.42 & 2.54 & 0.286 & 10.6 \\
\hline \multirow[t]{2}{*}{$12803-5 d$} & \multirow[t]{2}{*}{$\mathrm{A}_{1}$} & Core & 9.69 & 2.25 & 48.62 & 36.63 & 0.44 & 2.22 & 0.285 & 9.0 \\
\hline & & Rim & 9.79 & 2.52 & 48.22 & 36.12 & 0.37 & 2.63 & 0.289 & 12.7 \\
\hline \multirow[t]{2}{*}{$12803-8 b$} & \multirow[t]{2}{*}{$\mathrm{A}_{1}$} & Core & 9.85 & 2.30 & 48.22 & 37.10 & 0.44 & 2.02 & 0.290 & 8.1 \\
\hline & & Rim & 9.41 & 2.97 & 48.57 & 35.48 & 0.36 & 2.98 & 0.279 & 14.5 \\
\hline \multirow[t]{2}{*}{$12803-8 \mathrm{R} 1$} & \multirow[t]{2}{*}{$\mathrm{A}_{1}$} & Core & 9.24 & 2.26 & 49.52 & 36.18 & 0.38 & 2.32 & 0.272 & 10.7 \\
\hline & & Rim & 9.58 & 2.67 & 48.28 & 36.40 & 0.35 & 2.46 & 0.284 & 12.4 \\
\hline \multirow[t]{2}{*}{$12803-9 b$} & $\mathrm{~A}_{1}$ & Core & 9.80 & 2.27 & 48.23 & 37.02 & 0.44 & 2.08 & 0.289 & 8.2 \\
\hline & & Rim & 9.26 & 3.07 & 48.62 & 35.34 & 0.35 & 3.06 & 0.276 & 15.5 \\
\hline $12803-11 b$ & $\mathrm{~A}_{1}$ & Core & 9.82 & 2.40 & 48.16 & 36.88 & 0.41 & 2.20 & 0.289 & 9.5 \\
\hline & & Rim & 9.48 & 3.06 & 48.29 & 35.70 & 0.36 & 2.87 & 0.282 & 14.0 \\
\hline $12803-28 b$ & $\mathrm{~A}_{1}$ & Core & 9.74 & 2.25 & 48.47 & 36.83 & 0.45 & 2.11 & 0.287 & 8.3 \\
\hline & & Rim & 10.38 & 2.36 & 47.09 & 36.77 & 0.39 & 2.67 & 0.306 & 12.0 \\
\hline $12802-8 \mathrm{~g} 1$ & $A_{1}{ }^{\prime}$ & Core & 9.82 & 2.65 & 48.06 & 36.44 & 0.37 & 2.54 & 0.290 & 12.0 \\
\hline & & Rim & 9.58 & 3.23 & 47.78 & 35.99 & 0.37 & 2.79 & 0.286 & 13.4 \\
\hline $12802-39$ & $A_{1}$, & Core & 9.58 & 2.71 & 48.46 & 36.10 & 0.39 & 2.63 & 0.283 & 11.9 \\
\hline & & Rim & 9.70 & 3.24 & 47.62 & 36.19 & 0.39 & 2.66 & 0.290 & 11.9 \\
\hline $12803-11 \mathrm{c}$ & $A_{1}{ }^{\prime}$ & Core & 10.04 & 2.46 & 47.73 & 36.63 & 0.40 & 2.50 & 0.296 & 10.9 \\
\hline & & Rim & 9.96 & 2.86 & 47.45 & 36.54 & 0.38 & 2.62 & 0.295 & 12.0 \\
\hline $12802-4 b$ & $\mathrm{~B}$ & Core & 11.54 & 2.83 & 44.52 & 38.08 & 0.42 & 2.50 & 0.341 & 10.5 \\
\hline & & Rim & 10.17 & 3.31 & 46.96 & 35.69 & 0.32 & 3.35 & 0.302 & 18.5 \\
\hline $12802-40$ & B & Core & 11.18 & 2.87 & 45.15 & 37.77 & 0.43 & 2.48 & 0.331 & 10.2 \\
\hline & & Rim & 10.06 & 3.68 & 46.89 & 35.32 & 0.35 & 3.54 & 0.300 & 17.7 \\
\hline $12802-8 \mathrm{~g} 3$ & $\mathrm{~B}^{\prime}$ & Core & 9.20 & 3.66 & 48.29 & 35.19 & 0.32 & 3.18 & 0.276 & 17.7 \\
\hline & & Rim & 8.51 & 4.02 & 49.15 & 34.76 & 0.33 & 3.04 & 0.257 & 16.3 \\
\hline $12803-15 b$ & $\mathrm{~B}^{\prime}$ & Core & 9.61 & 3.37 & 47.93 & 35.36 & 0.31 & 3.25 & 0.286 & 18.2 \\
\hline & & Rim & 9.20 & 3.78 & 48.19 & 35.02 & 0.34 & 3.24 & 0.276 & 17.0 \\
\hline $12803-28 \mathrm{~d}$ & $\mathrm{~B}^{\prime}$ & Core & 10.41 & 3.13 & 46.57 & 35.84 & 0.36 & 3.41 & 0.309 & 16.5 \\
\hline & & Rim & 8.65 & 3.98 & 48.77 & 34.86 & 0.34 & 3.06 & 0.262 & 16.0 \\
\hline White pumice & & & & & & & & & & \\
\hline wp1-1 & $\mathrm{A}_{0}$ & Core & 9.53 & 2.10 & 48.98 & 36.93 & 0.45 & 1.90 & 0.280 & 7.4 \\
\hline & & Rim & 9.42 & 2.22 & 48.48 & 36.98 & 0.42 & 2.08 & 0.280 & 8.7 \\
\hline wp3-1 & $\mathrm{A}_{0}$ & Core & 9.44 & 2.16 & 49.04 & 36.99 & 0.43 & 1.83 & 0.278 & 7.5 \\
\hline & & Rim & 9.55 & 2.11 & 48.85 & 36.95 & 0.44 & 1.96 & 0.281 & 7.9 \\
\hline wp5-1 & $\mathrm{A}_{0}$ & Core & 9.67 & 2.00 & 48.54 & 37.12 & 0.45 & 1.89 & 0.285 & 7.4 \\
\hline & & Rim & 9.93 & 2.14 & 48.05 & 37.19 & 0.39 & 2.10 & 0.292 & 9.4 \\
\hline wp1-2 & $A_{1}$ & Core & 9.66 & 2.41 & 48.53 & 36.84 & 0.47 & 2.04 & 0.285 & 7.7 \\
\hline & & Rim & 9.67 & 2.36 & 48.16 & 36.80 & 0.44 & 2.11 & 0.286 & 8.5 \\
\hline wp1-3 & $\mathrm{A}_{1}$ & Core & 9.73 & 2.34 & 48.31 & 37.00 & 0.47 & 2.03 & 0.287 & 7.6 \\
\hline & & Rim & 9.62 & 2.41 & 48.17 & 36.98 & 0.42 & 2.08 & 0.285 & 8.7 \\
\hline
\end{tabular}

Values were recalculated to ensure a non-volatile total of $100 \mathrm{wt} \%$ 


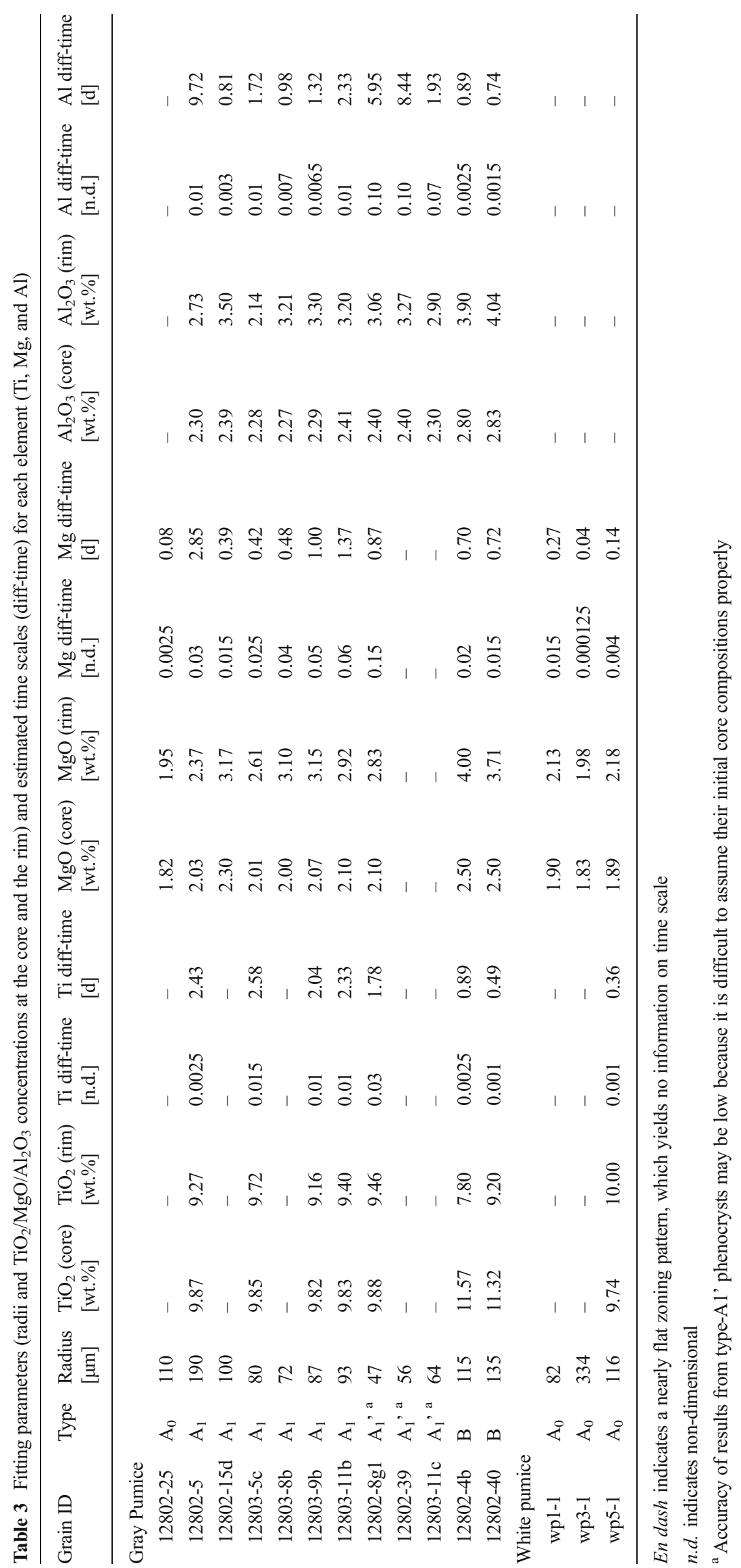



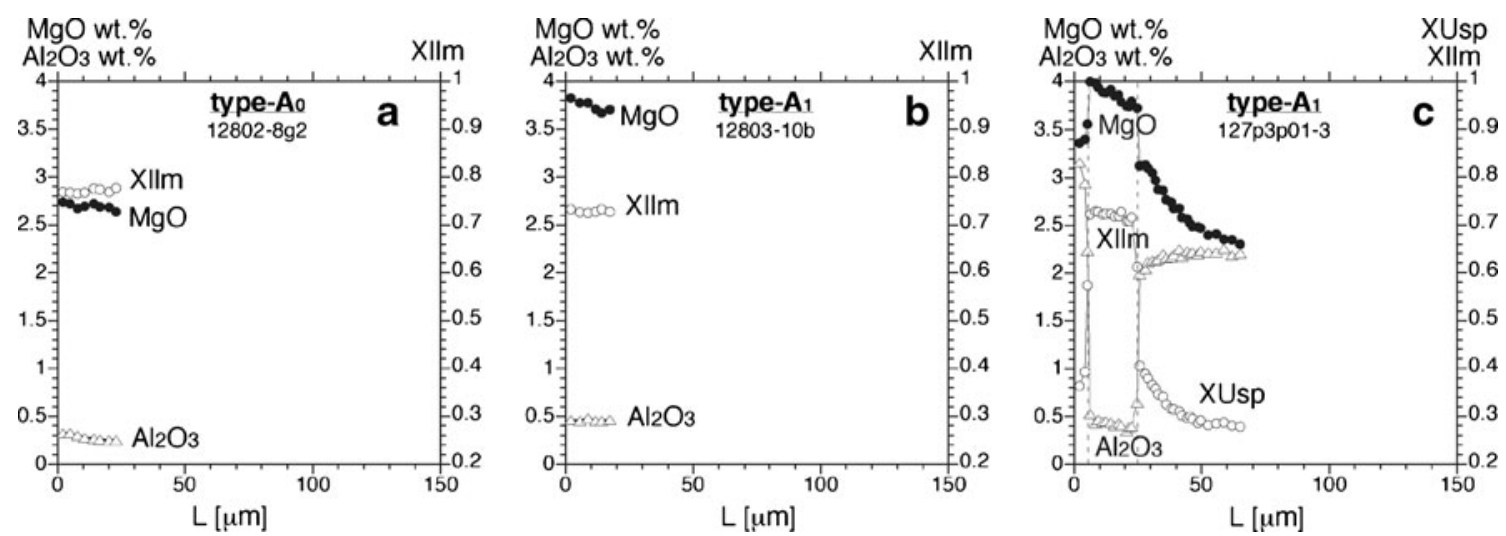

Fig. 11 Zoning profiles of ilmenite. a Type- $A_{0}$ ilmenite; $\mathbf{b}$ type- $A_{1}$ ilmenite; $\mathbf{c}$ aggregate of type- $A_{1}$ ilmenite $(5-25 \mu m)$ and type- $A_{1}$ magnetite $(>25 \mu \mathrm{m})$ in contact. The outermost layer $(<5 \mu \mathrm{m})$ is a reaction rim of magnetite

Mixing processes

Figure 12 shows a schematic diagram of the magma-mixing processes just prior to the 2011 eruption. Mixing between magmas $A_{1}, B$, and $X$ formed the significant reverse zoning of types $A_{1}$ and $B$ magnetite. Hereafter, we refer to this process $\left(\mathrm{A}_{1}+\mathrm{B}+\mathrm{X}\right)$ as mixing $\mathrm{I}$. An additional mixing with magmas $\mathrm{A}_{0}$ formed the slight reverse zoning of type $\mathrm{A}_{0}$ magnetite. Hereafter, we refer to this latter process $\left(+\mathrm{A}_{0}\right)$ as mixing II. Gray pumice was formed by two-stage mixing $\left(\mathrm{A}_{1}+\mathrm{B}+\mathrm{X}\right)+\mathrm{A}_{0}$; mixing I initially formed the main part of the gray pumice, and mixing II modified it. White pumice was formed only by mixing II $\left(\mathrm{A}_{1}+\right.$ $\mathrm{A}_{0}$ ). Banded pumice was formed in the later stage of mixing II.

Magma $\mathrm{A}_{1}$ already had slightly higher temperatures and was slightly more mafic than magma $\mathrm{A}_{0}$ when mixing I began. This result was deduced from the higher $\mathrm{Mg}$ and $\mathrm{Al}$ cores of type $\mathrm{A}_{1}$ magnetite over those of type $A_{0}$ (Fig. 8). Therefore, Magma $A_{1}$, the main component of the 2011 eruptive products, could have been a mobile layer (Burgisser and Bergantz 2011) that was formed long before the eruption by reheating of the mushy magma body (magma $\mathrm{A}_{0}$ ). Eruption of mobile-layer magma is often a precursory phase of large Plinian eruptions (Takeuchi 2004, 2011). In such cases, the eruptive products of the main Plinian phase are composed of phenocryst-rich silicic magma from the main part of a mushy magma chamber. Because of high viscosity, the mushy main part is not able to erupt solely but can follow less-viscous precursory magma, which occurred during the 1991 eruption of Pinatubo (Pallister et al. 1992) and the 1929 eruption of Hokkaido-Komagatake (Takeuchi and Nakamura 2001). In the cases of the 2011 eruptions of
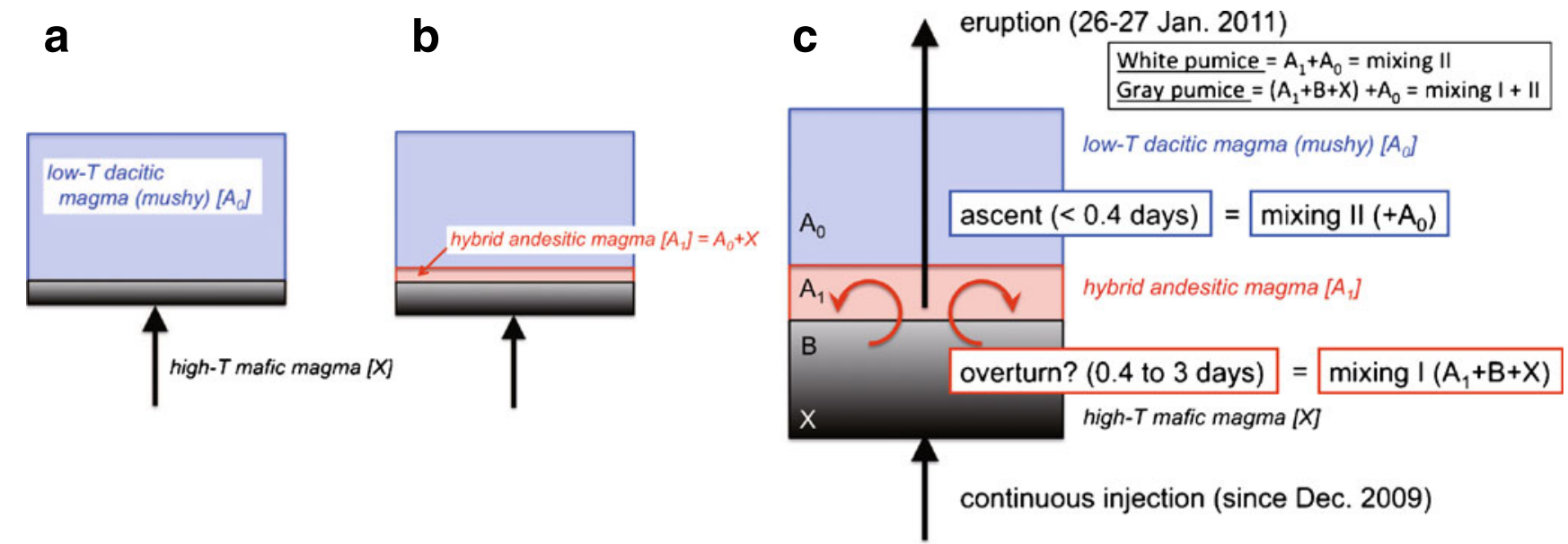

start

continued

continuous inflation

Fig. 12 Schematic diagrams of the magma-mixing processes prior to the 2011 eruption of Shinmoedake (not to scale). a High-temperature mafic magma $(X)$ was injected into a magma chamber composed of lowtemperature dacitic mushy magma $\left(A_{0}\right)$ likely since December 2009. b The injection continued and formed a hybrid andesite $\left(\mathrm{A}_{1}\right)$ by heating and re-melting of the low-temperature magma by (and mixing with) the mafic magma. c The injection continued; the hybrid andesite amount increased, and further mixed magma $(B)$ was formed. Magma mixing between magmas $\mathrm{A}_{1}, \mathrm{~B}$, and $\mathrm{X}$ (mixing I) occurred 0.4 to 3 days before the subPlinian eruptions, likely due to magmatic overturn within the magma chamber. Ascent of mainly $A_{1}$ magma began, incorporating magma $A_{0}$ (mixing II), less than 0.4 days before the sub-Plinian eruptions 
Table 4 Characteristics of the magma members and interpretation

\begin{tabular}{llllll}
\hline Member & Magnetite & Ilmenite & Silicate minerals & Temperature & Interpretation \\
\hline Magma $\mathrm{A}_{0}$ & Type $\mathrm{A}_{0}$ & Type $\mathrm{A}_{0}$ & Low-Ca pl, opx, cpx & ca. $875{ }^{\circ} \mathrm{C}$ & Low-temperature end-member magma (SiO ${ }_{2} \geq 63$ wt.\%) \\
Magma $\mathrm{A}_{1}$ & Type $\mathrm{A}_{1}\left(+\mathrm{A}_{1}{ }^{\prime}\right)$ & Type $\mathrm{A}_{1}$ & Low-Ca pl, opx, cpx ${ }^{\mathrm{a}}$ & ca. $890{ }^{\circ} \mathrm{C}$ & Slightly heated and mixed low-T magma \\
Magma B & Type B $\left(+\mathrm{B}^{\prime}\right)$ & No ilm & Low-Ca pl, opx, cpx ${ }^{\mathrm{a}}$ & $900-950{ }^{\circ} \mathrm{C}$ & More heated and mixed low-T magma \\
Magma X & No mt & No ilm & High-Ca pl, ol & ca. $1100{ }^{\circ} \mathrm{C}$ & High-temperature end-member magma (SiO ${ }_{2} \leq 54$ wt.\%)
\end{tabular}

The January 26-27, 2011, eruptive products consisted mainly of magma $\mathrm{A}_{1}$. Magmas $\mathrm{A}_{0}$ and $\mathrm{X}$ were the end-member magmas, whereas magmas $\mathrm{A}_{1}$ and $\mathrm{B}$ were formed by heating and mixing by magma $\mathrm{X}$ into magma $\mathrm{A}_{0}$ : $m t$ magnetite, $i l m$ ilmenite, $p l$ plagioclase, opx orthopyroxene, $c p x$ clinopyroxene, ol olivine

${ }^{a}$ A small amount of high-Ca pl and ol (from magma X) may be included

Shinmoedake, however, the main part (magma $\mathrm{A}_{0}$ ) did not erupt as a large Plinian eruption. This result may indicate that the magma chamber of Shinmoedake did not have sufficient eruptibility (Takeuchi 2011) at that time and that only the mobile layer (magma $A_{1}$ ) could erupt with a minor contribution of the main part (magma $\mathrm{A}_{0}$ ) of the magma chamber.

\section{Discussion 2: time scales of the magma-mixing processes}

Diffusion coefficients in magnetite

Diffusion coefficients and chemical behaviors of $\mathrm{Mg}$ and $\mathrm{Al}$ differ from those of Ti. We combined these elements in order to (1) distinguish whether the zoning profiles were formed by diffusion or crystal growth, (2) detect processes that did not change Ti content, and (3) estimate shorter time scales than those estimated by Ti diffusion.

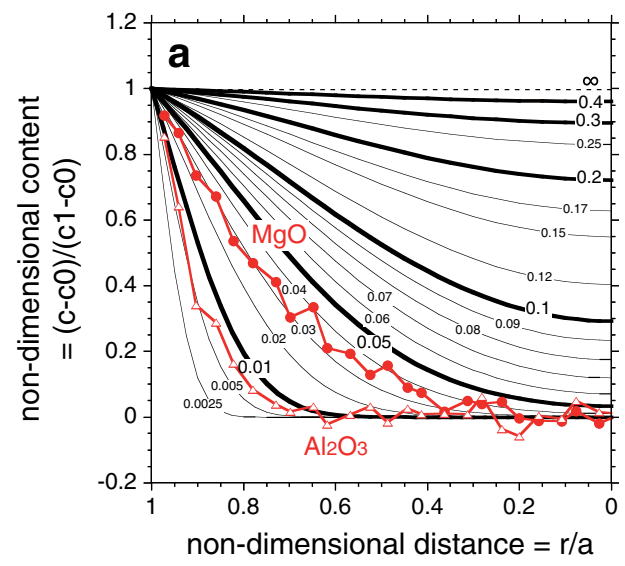

Fig. 13 a Calculated diffusion profiles in an isotropic sphere (black curves) and typical zoning profiles (red curves; grain 12803-8b). The distance from the center $r$ and the contents $c$ (e.g., $\mathrm{MgO} \mathrm{wt} \%$ ) are normalized to non-dimensional distance $r / a$ and non-dimensional content $(c-c 0) /(c 1-c 0)$, where $a$ is the radius, $c 0$ is the initial content, and $c 1$ is the content at the rim. The figures accompanying the black curves denote nondimensional time $D t / a^{2}$, where $t$ is the time and $D$ is the diffusion
The diffusion coefficient depends on various factors such as temperature, oxygen fugacity, and chemical composition. We calculated the diffusion coefficient of Ti by using the equation of Van Orman and Crispin (2010) with a temperature of $950{ }^{\circ} \mathrm{C}, \log \mathrm{fO}_{2}=-11$, and $\mathrm{XUsp}=0.3$, which corresponds to the conditions just after the mixing of magmas $\mathrm{A}_{1}$ and $\mathrm{B}$. The diffusion coefficient of $\mathrm{Al}$ is assumed to be the same as that of $\mathrm{Ti}$ because the available diffusion coefficient data for $\mathrm{Al}$ and $\mathrm{Ti}$ are similar (Van Orman and Crispin 2010). Moreover, the diffusion widths of these elements in our zoning profiles are similar (Fig. 10). Thus, we obtained a coefficient of $4.3 \times$ $10^{-16} \mathrm{~m}^{2} / \mathrm{s}$ for $\mathrm{Ti}$ and $\mathrm{Al}$. If we assume a temperature of $900{ }^{\circ} \mathrm{C}$, which corresponds to the condition at the beginning of the magma mixing, we obtain $6.9 \times 10^{-16} \mathrm{~m}^{2} / \mathrm{s}$. The reason why diffusion coefficient increases with decreasing temperature (e.g., Fig. 23 of Van Orman and Crispin 2010) is that a vacancy mechanism, which has strong negative activation enthalpy, becomes dominant in lower temperatures than those

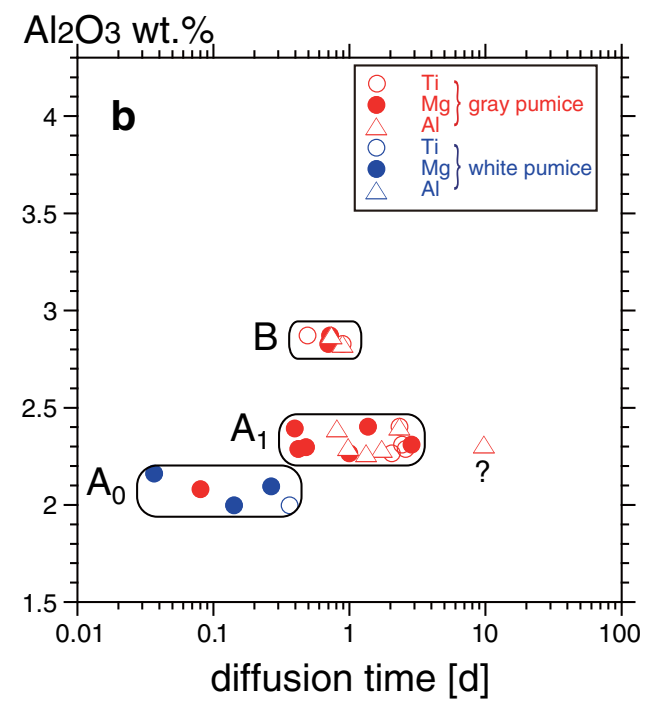

coefficient. Parameters for the non-dimensionalization are listed in Table 3. b Time scales of the magma-mixing processes prior to the sub-Plinian eruptions estimated from zoning profiles of types $\mathrm{A}_{0}, \mathrm{~A}_{1}$, and $\mathrm{B}$ magnetite phenocrysts. Reverse zoning of type $A_{0}$ recorded mixing $I$, whereas that of types $\mathrm{A}_{1}$ and $\mathrm{B}$ recorded mixing II. The estimated time scales may have an error of a factor 2 to 4 or more. The outlier with a question mark was excluded from calculation of average diffusion time 
occurring with an interstitial mechanism. Therefore, the diffusion coefficient has a minimum value at a temperature of approximately $980^{\circ} \mathrm{C}$ for Ti. The error caused by temperature uncertainty is thus small (less than a factor of 2) because the temperature of concern is near this minimum value.

The diffusion coefficient of $\mathrm{Mg}$ in magnetite has rarely been reported and has not been cited even in the most comprehensive review papers (e.g., Costa et al. 2008; Van Orman and Crispin 2010). Only experiments by Semberg et al. (2011) estimated the value to be approximately $10^{-15}$ to $10^{-16} \mathrm{~m}^{2} / \mathrm{s}$ at $900^{\circ} \mathrm{C}$. We here consider the coefficient to be the same as that of $\mathrm{Fe}$ for the following reasons: The available diffusion coefficient data of divalent cations of $\mathrm{Fe}, \mathrm{Mn}, \mathrm{Co}$, and $\mathrm{Ni}$ are similar and are significantly higher than those of $\mathrm{Ti}$ and $\mathrm{Al}$ under our conditions of interest (Van Orman and Crispin 2010); the diffusion coefficients of $\mathrm{Mg}$ and $\mathrm{Fe}$ are the same in spinel (Liermann and Ganguly 2002), which is a mineral similar to magnetite; and the diffusion widths of $\mathrm{Mg}$ and $\mathrm{Fe}$ in our zoning profiles are similar. Because the zoning profiles of $\mathrm{Mg}$ and Fe are complementary with an $\mathrm{Mg}$ increase accompanied by an Fe decrease and vice versa (Fig. 10), coupled diffusion is indicated between the cations. The diffusion coefficient of $\mathrm{Fe}$ was calculated by using the equation of Van Orman and Crispin (2010) with the same condition as for Ti. Thus, we obtained $4.4 \times 10^{-15} \mathrm{~m}^{2} / \mathrm{s}$ for $\mathrm{Mg}$, which is consistent with the experimental results of Semberg et al. (2011). If we assume a temperature of $900{ }^{\circ} \mathrm{C}$, we obtain $6.6 \times 10^{-15} \mathrm{~m}^{2} / \mathrm{s}$. The diffusion coefficient for $\mathrm{Fe}$ has a minimum value at about $950{ }^{\circ} \mathrm{C}$; therefore, the error caused by temperature uncertainty is also small at less than a factor of 2 .

\section{Fitting calculation}

We estimated diffusion time to constrain the time scales of the magma mixing by fitting a simple diffusion model to the observed zoning profiles (Fig. 13a). We considered a grain as an isotropic sphere with homogeneous initial composition, fixed rim composition during diffusion, and no crystal growth to obtain a simple, spherically symmetrical diffusion model (e.g., equation 6.1 and Fig. 6.1 of Crank 1975). We solved the diffusion equation numerically by using the finite difference method. Examples of fitting calculations are shown in Figs. 9b and 13a; fitting parameters and estimated time scales are listed in Table 3.

\section{Estimated time scales from magma mixing to eruption}

The estimated time scales are shown in Fig. 13b; each point corresponds to one zoning profile. The estimated time scales may have an error of a factor 2 to 4 or more (Costa et al. 2008) due to the error of fitting, the uncertainties in the diffusion coefficients, and possible sectioning effects.

The estimated diffusion time of type $A_{1}$ magnetite is 0.4 to 3 days with an average of 1.1 days, and that of type $B$ magnetite is 0.5 to 0.9 days (Fig. 13b). These times correspond to the time of mixing I until eruption. The diffusion time of type B' magnetite can also be calculated if the proper initial conditions are chosen. However, it is difficult to determine such conditions properly for type B' magnetite because there are no flat cores, which are the most probable initial conditions. Thus, the time scales of type B' magnetite are not discussed here. The diffusion time of type $\mathrm{A}_{0}$ magnetite is 0.04 to 0.4 days with an average of 0.13 days (Fig. 13b); this time corresponds to the time of mixing II until eruption. The lower limit is further lowered if we consider the grains with no reverse zoning, which represent almost no diffusion time. Most of the time scales obtained by previous studies for pre-eruptive processes that used zoning profiles of phenocrysts were a few days to a few years (Costa et al. 2008). The estimated time scales for mixing I and mixing II thus belong to the shortest group among them.

Deduced from its significant effects on zoning profiles, mixing I was the dominant process and likely triggered the eruption. Mixing II followed mixing I because the time scale was shorter than and almost continuous with that of mixing I. Mixing II was thus a subordinate process and likely accompanied magma ascent. Formation of banded pumice occurred during ascent in the later stage of mixing II. Thus, mixing I was pre-eruptive mixing, whereas mixing II was syn-eruptive mixing. However, they could have occurred sequentially, likely by a single triggering mechanism.

It may have been possible for additional mixing events to occur prior to mixing I that were not recorded in magnetite because this mineral was completely re-equilibrated; however, we can show that this possibility is unlikely given the following. The maximum (upper limit) diffusion time that we can detect, $t_{\max }$, is estimated to be $t_{\max } \sim 0.4 a^{2} / D$ because a zoning profile with non-dimensional time $\left(D t / a^{2}\right)$ larger than approximately 0.4 is almost flat and yields no information (Fig. 13a). For example, the $t_{\max }$ of $\mathrm{Ti}$ and $\mathrm{Al}$ in magnetite is 108 days when the radius $a$ is $100 \mu \mathrm{m}$. The estimated non-dimensional times for mixing I are well below this upper limit $\left(D t / a^{2}<0.4\right.$; Table 3). Furthermore, no mixing events occurred between mixing I and $t_{\max }$ prior to the January 26-27, 2011, eruptions. On the other hand, we could not detect mixing events that occurred more than $t_{\max }$ prior to the eruptions.

We therefore obtained time scales from zoning profiles of Mg in olivine phenocrysts (Fig. 7b; Saito 2012; Saito (2012, in preparation)) because $t_{\max }$ for olivine was longer than that for magnetite. Olivine phenocrysts show normal zoning within several tens of microns from the rim. The diffusion model discussed previously (Crank 1975) gives diffusion times of 1 to 10 days by using $1.65 \times 10^{-16} \mathrm{~m}^{2} / \mathrm{s}$ as the diffusion coefficient of $\mathrm{Mg}$ for a- and b- axes in olivine at $960{ }^{\circ} \mathrm{C}$ (Johnson et al. 2008). These times are consistent with the time of mixing I obtained by types $\mathrm{A}_{1}$ and $\mathrm{B}$ magnetite. The $t_{\max }$ of $\mathrm{Mg}$ in olivine is 281 and 1,120 days when the radius is 100 and $200 \mu \mathrm{m}$, respectively. Zoning profiles of olivine thus reveal 
Fig. 14 a Global Positioning System (GPS) observation by the Geospatial Information Authority of Japan (GSI) through which continuous inflation has been recorded since December 2009, adapted from the GSI website (http://mekira.gsi.go.jp/bousai/ kirishima/pdf/kirishima_hp_long_ 1.pdf). b Tiltmeter observation by the Japan Meteorological Agency (JMA). Remarkable deflation was observed during the sub-Plinian eruptions and lava effusion. The data were obtained from JMA. c Time scales of magma-mixing processes estimated by magnetite analysis. Significant crustal deformation was not observed at the time of the magma mixing I, which occurred 0.4 to 3 days before the sub-Plinian eruption (P2)

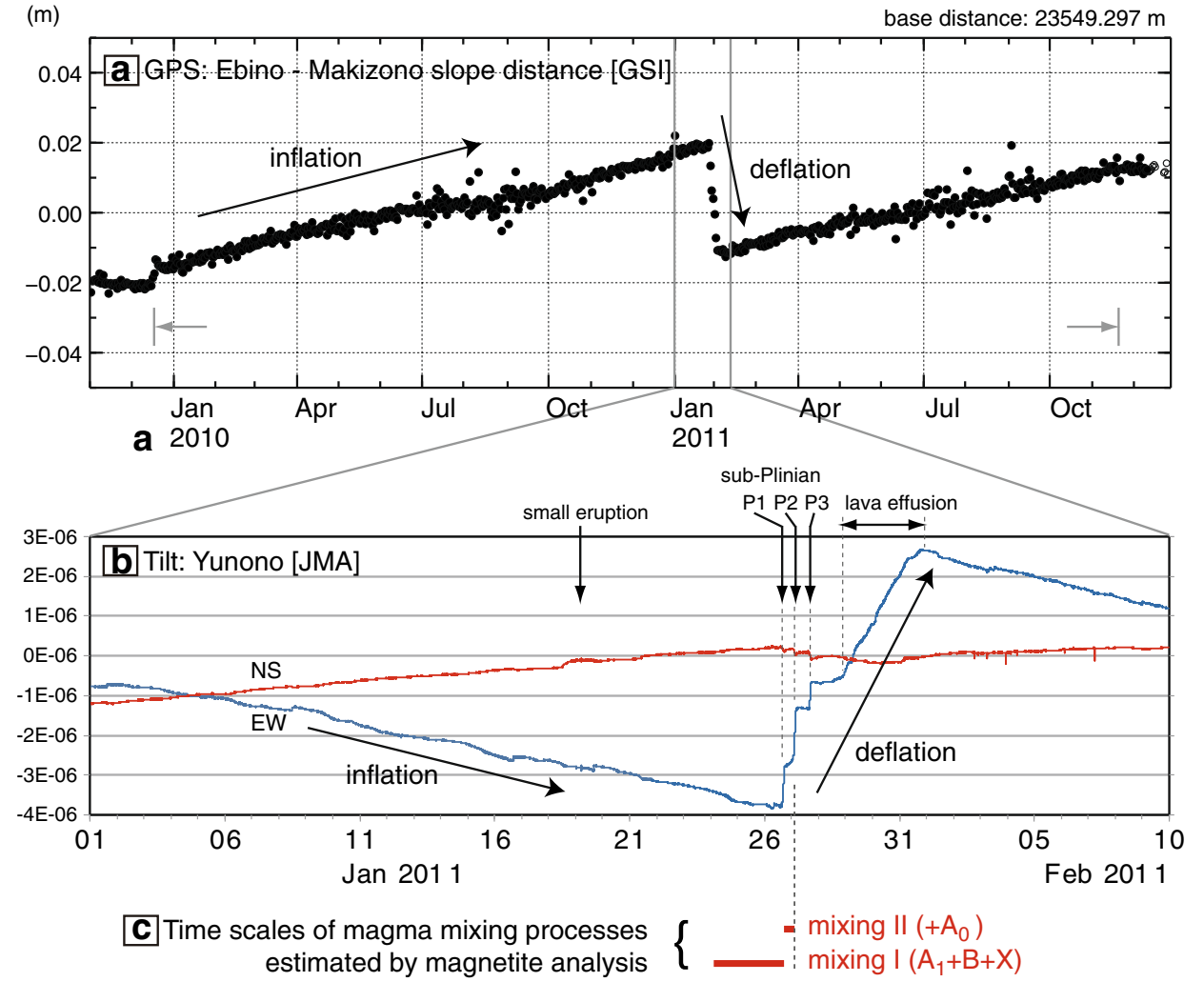

that the mafic magma did not significantly mix into the silicic magma for months or years until that occurring 1 to 10 days prior to the eruption.

\section{Magma-mixing process without crustal deformation}

We determined that a significant magma-mixing process (mixing I) occurred 0.4 to 3 days prior to the sub-Plinian eruptions (Fig. 13b). Then, we compared the result with geodetic observations. Continuous inflation has been observed by Global Positioning System (GPS) since December 2009 (Kawamoto et al. 2011), and remarkable deflation was observed by GPS and tiltmeters during the sub-Plinian eruptions and lava effusion (Ueda et al. 2013). However, no significant change was observed within several days before the sub-Plinian eruptions (Fig. 14), as well as no increase in seismicity. Therefore, mixing I was not accompanied by a significant change in volume of the magma chamber. We consider that magmatic overturn of a preexisting stratified magma chamber (e.g., Ruprecht et al. 2008; Woods and Cowan, 2009; Burgisser and Bergantz 2011) or melt accumulation within the magma chamber (e.g., Gudmundsson 2012) is probable. Injection of a new magma batch from the outside, on the contrary, can be excluded because it should be accompanied by significant volume change.

The time difference between the beginning of magma mixing and that of magma injection may vary among volcanoes; here, we consider that the former is recorded in crystals, and the latter is observed as volcanic unrest, including crustal deformation.
The former and the latter were several days and 13 months prior to the 2011 eruption of Shinmoedake, respectively. On the other hand, Kahl et al. (2011, 2013) determined that the beginning of magma mixing recorded in olivine crystals from a recent eruption of Mt. Etna correlates to that of several signs of volcanic unrest. In the case of Etna, the contrast between the mixing end members was smaller, and both magmas were less viscous than those of Shinmoedake, so that the magmas could have easily mixed with no significant time difference.

Finally, we consider the re-homogenization process of type $A_{0}$ magnetite into type $A_{1}$ magnetite in the hybrid magma or mobile layer (Fig. 12). The re-homogenization process is implied because the type $A_{1}$ magnetite is homogeneous in white pumice (Fig. 10b, f, j, n). The formation of homogeneous type $A_{1}$ grains by diffusion of type $A_{0}$ grains requires a minimum of about 30 days, according to the $t_{\max }$ of Ti and $\mathrm{Al}$ in magnetite. The re-homogenization time is consistent with the beginning of ground inflation in December 2009; therefore, the formation of the hybrid magma and the ground inflation may have begun at the same time.

The injection of high-temperature mafic magma into the preexisting mushy silicic magma was likely continuous and gradual over 13 months from December 2009, as evidenced by the continuous inflation. The density and viscosity contrast between the mafic and silicic magmas prevented the mafic injection from causing an immediate eruption and instead initially resulted in stable stratified magma layers (Fig. 12a, b). The silicic magma was heated by the underlying mafic magma and 
was partly re-melted and loosened to form a mobile layer (hybrid andesite in Fig. 12) (e.g., Jellinek and Kerr 1999; Kaneko and Koyaguchi 2004; Burgisser and Bergantz 2011). Despite continuous injection, eruptions and further significant mixing did not occur until this relatively static process suddenly changed to a dynamic process to exhibit overturn on January 2011. The mechanism of this sudden change is an important issue in the forecasting of eruptions. Since such activity is difficult to detect by geodetic and seismic observations, we should consider additional methods appropriate for such processes.

\section{Conclusions}

We estimated time scales of magma-mixing processes just prior to the 2011 sub-Plinian eruptions of Shinmoedake volcano mainly on the basis of zoning analysis of magnetite phenocrysts. A significant pre-eruptive mixing process, mixing I, occurred several days before the eruptions and triggered the eruptions. Because this process was not accompanied by significant crustal deformation, magmatic overturn within the magma chamber was a probable mechanism. In addition, subordinate syn-eruptive mixing processes, mixing II, occurred only several hours prior to eruptions during the magma ascent. These mixing events likely occurred continually before and after the beginning of the eruptions. Mafic injection began more than several tens of days prior to mixing I, likely coinciding with the beginning of the inflation in December 2009, to form the hybrid andesite mobile layer. This hybrid andesite was the main eruptive component of the 2011 eruptions of Shinmoedake.

Acknowledgments We thank Ryuta Furukawa, Shun Nakano, Teruki Oikawa, Tetsuo Kobayashi, and the Japan Meteorological Agency (JMA) for providing the samples used in this research. Teruki Oikawa also provided photos of pumice. We thank the JMA and the Geospatial Information Authority of Japan for providing geodetic data. We acknowledge valuable discussions with Hiroshi Shinohara and Shingo Takeuchi. Comments on the earlier version by Mary R. Reid were very helpful in improving the manuscript. Careful reading and valuable comments by Paul J. Wallace and two anonymous reviewers greatly improved the manuscript. This work was partly supported by a Japan Society for the Promotion of Science (JSPS) Grant-in-Aid for Scientific Research (KAKENHI No. 23540564 to A.T.).

Open Access This article is distributed under the terms of the Creative Commons Attribution License which permits any use, distribution, and reproduction in any medium, provided the original author(s) and the source are credited.

\section{References}

Andersen DJ, Lindsley DH (1985) New (and final!) models for the Timagnetite/ilmenite geothermometer and oxygen barometer. Abstract AGU 1985 Spring Meeting. Eos Trans AGU 66(18):416
Bacon CR, Hirschmann MM (1988) Mg/Mn partitioning as a test for equilibrium between coexisting Fe-Ti oxides. Am Mineral 73:57-61

Blundy J, Cashman K (2008) Petrologic reconstruction of magmatic system variables and processes. Rev Mineral Geochem 69:179 239. doi:10.2138/rmg.2008.69.6

Burgisser A, Bergantz GW (2011) A rapid mechanism to remobilize and homogenize highly crystalline magma bodies. Nature 471:212-215. doi:10.1038/nature09799

Chertkoff DG, Gardner JE (2004) Nature and timing of magma interactions before, during, and after the caldera-forming eruption of Volcán Ceboruco, Mexico. Contrib Mineral Petrol 146:715-735. doi:10.1007/s00410-003-0530-6

Coombs M, Eichelberger J, Rutherford M (2000) Magma storage and mixing conditions for the 1953-1974 eruptions of Southwest Trident volcano, Katmai National Park, Alaska. Contrib Mineral Petrol 140:99-118. doi:10.1007/s004100000166

Costa F, Chakraborty S (2004) Decadal time gaps between mafic intrusion and silicic eruption obtained from chemical zoning patterns in olivine. Earth Planet Sci Lett 227:517-530. doi:10.1016/j.eps1.2004. 08.011

Costa F, Chakraborty S, Dohmen R (2003) Diffusion coupling between trace and major elements and a model for calculation of magma residence times using plagioclase. Geochim Cosmochim Acta 67:2189-2200. doi:10.1016/S0016-7037(00) 01345-5

Costa F, Dohmen R, Chakraborty S (2008) Time scales of magmatic processes from modeling the zoning patterns of crystals. Rev Mineral Geochem 69:545-594. doi:10.2138/rmg.2008.69.14

Crank J (1975) The mathematics of diffusion (2nd ed.). Oxford University Press, New York, NY

Dare SAS, Barnes S-J, Beaudoin G (2012) Variation in trace element content of magnetite crystallized from a fractionating sulfide liquid, Sudbury, Canada: implications for provenance discrimination. Geochim Cosmochim Acta: 88:27-50. doi:10.1016/j.gca.2012.04. 032

Devine JD, Rutherford MJ, Norton GE, Young SR (2003) Magma storage region processes inferred from geochemistry of $\mathrm{Fe}-\mathrm{Ti}$ oxides in andesitic magma, Soufrière Hills volcano, Montserrat, W.I. J Petrol 44:1375-1400. doi:10.1093/petrology/44.8.1375

Druitt TH, Costa F, Deloule E, Dungan M, Scaillet B (2012) Decadal to monthly timescales of magma transfer and reservoir growth at a caldera volcano. Nature 482:77-80. doi:10.1038/nature10706

Furukawa R, Geshi N, Nakano S, Hoshizumi H, Takarada S, Takeuchi S, Toshida K, Tajima Y, Tsutsui M (2011) Urgent survey of eruptive deposit in January, 2011, from Shinmoedake volcano, Mt. Kirishima, South Kyushu, Japan. Japan Geoscience Union Meeting 2011 (Abstract), SVC050-05

Gardner JR, Carey S, Rutherford M (1995) Petrologic diversity in Mount St. Helens dacites during the last 4,000 years: implications for magma mixing. Contrib Mineral Petrol 119:224-238. doi:10.1007/ BF00307283

Gerlach DC, Grove TL (1982) Petrology of Medicine Lake Highland volcanics: characterization of endmembers of magma mixing. Contrib Mineral Petrol 80:147-159

Geshi N (2008) Vertical and lateral propagation of radial dikes inferred from the flow-direction analysis of the radial dike swarm in Komochi Volcano, Central Japan. J Volcanol Geotherm Res 173:122-134. doi:10.1016/j.jvolgeores.2008.01.001

Geshi N, Takarada S, Tsutsui M, Mori T, Kobayashi T (2010) Products of the August 22, 2008 eruption of Shinmoedake, Kirishima Volcanic Group, Japan. Bull Volcanol Soc Jpn 55:53-64 (in Japanese with English Abstract)

Gudmundsson A (2012) Magma chambers: formation, local stresses, excess pressures, and compartments. J Volcanol Geotherm Res 237-238:19-41. doi:10.1016/j.jvolgeores.2012.05.015 
Huppert HE, Sparks RSJ (1988) The generation of granitic magmas by intrusion of basalt into continental crust. J Petrol 29:599-624. doi:10.1093/petrology/29.3.599

Imura R, Kobayashi T (1991) Eruptions of Shinmoedake volcano, Kirishima volcano group, in the last 300 years. Bull Volcanol Soc Jpn 36:135-148 (in Japanese with English abstract)

Jellinek AM, Kerr RC (1999) Mixing and compositional stratification produced by natural convection 2 . Applications to the differentiation of basaltic and silicic magma chambers and komatiite lava flows. J Geophys Res 104: doi:10.1029/1998JB900117

Johnson ER, Wallace PJ, Cashman KV, Granados HD, Kent AJR (2008) Magmatic volatile contents and degassing-induced crystallization at Volcan Jorullo, Mexico: implications for melt evolution and the plumbing systems of monogenetic volcanoes. Earth Planet Sci Lett 269:478. doi:10.1016/j.eps1.2008.03.004

JMA (Japan Meteorological Agency), Yamasato H (2011) Eruption of Shinmoedake volcano, Kirishimayama, 2011 (Outline). Japan Geoscience Union Meeting 2011 (Abstract), SVC050-02

Kahl M, Chakraborty S, Costa F, Pompilio M (2011) Dynamic plumbing system beneath volcanoes revealed by kinetic modeling, and the connection to monitoring data: an example from Mt. Etna. Earth Planet Sci Lett 308:11-22. doi:10.1016/j.epsl.2011.05.008

Kahl M, Chakraborty S, Costa F, Pompilio M, Liuzzo M, Viccaro M (2013) Compositionally zoned crystals and real-time degassing data reveal changes in magma transfer dynamics during the 2006 summit eruptive episodes of Mt. Etna Bull Volcanol 75:692. doi:10.1007/ s00445-013-0692-7

Kaneko K, Koyaguchi T (2004) Experimental study on the effects of crustal temperature and composition on assimilation with fractional crystallization at the floor of magma chambers. J Volcanol Geotherm Res 129:155-172. doi:10.1016/S0377-0273(03)00238-5

Kawamoto S, Nogami K, Yokokawa M (2011) Crustal deformation associated with the eruption of Shinmoedake volcano, Kirishima volcanic group. J Geogr Surv Inst 121:179-182

Kozono T, Ueda H, Ozawa T, Koyaguchi T, Tomiya A, Suzuki YJ (2013) Magma discharge variations during the 2011 eruptions of Shinmoedake volcano, Japan, revealed by geodetic and satellite observations. Bull Volcanol 75: doi:10.1007/s00445-013-0695-4

La Tourrette TZ, Burnett DS, Bacon CR (1991) Uranium and minorelement partitioning in Fe-Ti oxides and zircon from partially melted granodiorite, Crater Lake, Oregon. Geochim Cosmochim Acta 55:457-469. doi:10.1016/0016-7037(91)90004-O

Liermann H-P, Ganguly J (2002) Diffusion kinetics of Fe and Mg in aluminous spinel: experimental determination and applications. Geochim Cosmochim Acta 66:2903-2913. doi:10.1016/S00167037(02)00875-X

Lindsley DH (1991) Experimental studies of oxide minerals. Rev Mineral Geochem 25:69-106

Lindsley DH, Frost BR (1992) Equilibria among Fe-Ti oxides, pyroxenes, olivine, and quartz: part I theory. Am Mineral 77:9871003

Martin VM, Morgan DJ, Jerram DA, Caddick MJ, Prior DV, Davidson JP (2008) Bang! Month-scale eruption triggering at Santorini Volcano. Science 321:1178-1178. doi:10.1126/science.1159584

Miyabuchi Y, Hanada D, Niimi H, Tetsuo K (2013) Stratigraphy, grainsize and component characteristics of the 2011 Shinmoedake eruption deposits, Kirishima Volcano, Japan. J Volcanol Geotherm Res 258:31-46. doi:10.1016/j.jvolgeores.2013.03.027

Nakamura M (1995) Residence time and crystallization history of nickeliferous olivine phenocrysts from the northern Yatsugatake volcanoes, Central Japan: application of a growth and diffusion model in the system Mg-Fe-Ni. J Volcanol Geotherm Res 66:81-100. doi:10. 1016/0377-0273(94)00054-K

Nakamura M (1996) Continuous mixing of crystal mush and replenished magma in the ongoing Unzen eruption. Geology 23: 807-810. doi:10.1130/0091-7613(1995)023<0807:CMOCMA >2.3.CO;2
Oikawa T, Furukawa R, Nakano S, Geshi N, Nishiki K, Miwa T, Shinohara H, Hoshizumi H, Tomiya A, Tanaka A (2011) Fallout tephra of the eruption of Shinmoedake in Kirishima volcanoes after January 28th, 2011. Japan Geoscience Union Meeting 2012 (Abstract), SVC070-P20

Pallister JS, Hoblitt RP, Reyes AG (1992) A basalt trigger for the 1991 eruptions of Pinatubo volcano? Nature 356:426-428. doi:10.1038/ $356426 \mathrm{a} 0$

Ruprecht P, Cooper KM (2012) Integrating the uranium-series and elemental diffusion geochronometers in mixed magmas from Volcán Quizapu, Central Chile. J Petrol 53:801-840. doi:10.1093/ petrology/egs001

Ruprecht, P Bergantz GW, Dufek J (2008) Modeling of gas-driven magmatic overturn: tracking of phenocryst dispersal and gathering during magma mixing. Geochem Geophys Geosyst, 9: Q07017. doi:10.1029/2008GC002022

Sack RO (1982) Spinels as petrogenetic indicators: activity-composition relations at low pressures. Contrib Mineral Petrol 79:169186

Saito G (2012) Magma mixing and degassing processes of 2011 eruption series of Kirishima volcano, Japan, based on chemical analyses of minerals and melt inclusions. Abstract AGU 2012 Fall Meeting, V53B-2830

Saito G, Geshi N, Shinohara H (2011) Magma mixing and degassing processes of Kirishima 2011 eruption based on chemical analyses of minerals and melt inclusions. Programme and Abstracts, The Volcanological Society of Japan, 2011 Fall Meeting, A2-08 (in Japanese)

Segall P (2010) Earthquake and volcanic deformation. Princeton University Press, Princeton

Semberg P, Rutqvist A, Andersson C, Bjorkman B (2011) Interaction between iron oxides and olivine in magnetite based pellets during reduction at temperatures below 1000 C. Ironmak Steelmak 38:321328. doi:10.1179/1743281210Y.0000000012

Shimbori T, Fukui K (2012) Time variation of the eruption cloud echo height from Shinmoe-dake volcano in 2011 observed by Tanegashima and Fukuoka weather radars: part II. Rep Coordinating Comm Prediction Volcanic Eruption 109:173-178

Shimono T, Minami H, Nishii Y, Ohno H, Watanabe K (2011) Observation of volcanic crater of Mt. Kirishima (Shinmoedake) by airborne SAR. J Geogr Surv Inst 121:189-194 (in Japanese)

Stormer JC Jr (1983) The effects of recalculation on estimates of temperature and oxygen fugacity from analyses of multi-component irontitanium oxides. Am Mineral 68:586-594

Suzuki Y, Yasuda A, Hokanishi N, Kaneko T, Nakada S, Fujii T (2013) Syneruptive deep magma transfer and shallow magma remobilization during the 2011 eruption of Shinmoe-dake, Japanconstraints from melt inclusions and phase equilibria experiments. J Volcanol Geotherm Res 257:184-204. doi:10.1016/j.jvolgeores. 2013.03.017

Takeuchi S (2004) Precursory dike propagation control of viscous magma eruptions. Geology 32:1001-1004. doi:10.1130/G20792.1

Takeuchi S (2011) Pre-eruptive magma viscosity: an important measure of magma eruptibility. J Geophys Res 116, B10201. doi:10.1029/ 2011JB008243

Takeuchi S, Nakamura M (2001) Role of precursory less-viscous mixed magma in the eruption of phenocryst-rich magma: evidence from the Hokkaido-Komagatake 1929 eruption. Bull Volcanol 63:365376. doi:10.1007/s004450100151

Tomiya A, Takahashi E (1995) Reconstruction of an evolving magma chamber beneath Usu volcano since the 1663 eruption. J Petrol 36:617-636. doi:10.1093/petrology/36.3.617

Tomiya A, Takahashi E (2005) Evolution of the magma chamber beneath Usu Volcano since 1663: a natural laboratory for observing changing phenocryst compositions and textures. J Petrol 46:2395-2426. doi:10.1093/petrology/egi057 
Toplis M, Corgne A (2002) An experimental study of element partitioning between magnetite, clinopyroxene and ironbearing silicate liquids with particular emphasis on vanadium. Contrib Mineral Petrol 144:22-37. doi:10.1007/s00410-0020382-5

Ueda H, Kozono T, Fujita E, Kohno Y, Nagai M, Miyagi Y, Tanada T (2013) Crustal deformation associated with the 2011 Shinmoe-dake eruption as observed by tiltmeters and GPS. Earth Planet Space 65:517-525

Van Orman JA, Crispin KL (2010) Diffusion in oxides. Rev Mineral Geochem 72:757-825. doi:10.2138/rmg.2010.72.17

Woods AW, Cowan A (2009) Magma mixing triggered during volcanic eruptions. Earth Planet Sci Lett 288:132-137. doi:10.1016/j.epsl. 2009.09.015 